\title{
Data report: permeability and microfabric of mud(stone) samples from IODP Sites C0011 and C0012, NanTroSEIZE subduction inputs ${ }^{1}$
}

\author{
Chen Song, ${ }^{2}$ Mehmet Koray Ekinci, ${ }^{2}$ Michael B. Underwood, ${ }^{2}$ and Pierre Henry ${ }^{3}$
}

\section{Chapter contents}

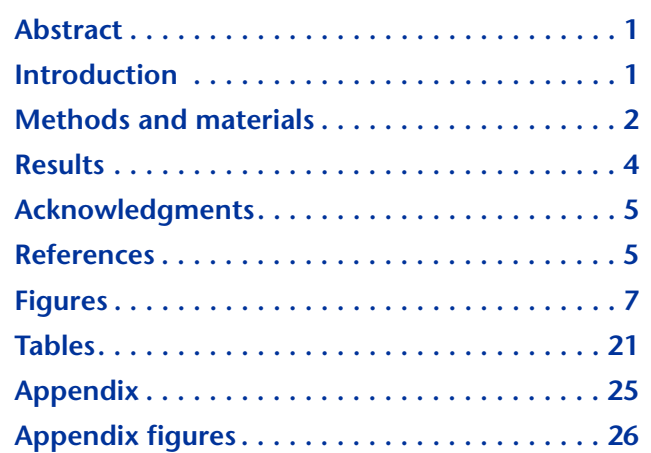

${ }^{1}$ Song, C., Ekinci, M.K., Underwood, M.B., and Henry, P., 2015. Data report: permeability and microfabric of mud(stone) samples from IODP Sites C0011 and C0012, NanTroSEIZE subduction inputs. In Saito, S., Underwood, M.B., Kubo, Y., and the Expedition 322 Scientists, Proc. IODP, 322: Tokyo (Integrated Ocean Drilling Program Management International, Inc.). doi:10.2204/iodp.proc.322.211.2015

${ }^{2}$ Department of Geological Sciences, University of Missouri, Columbia MO 65211, USA.

Correspondence author:

UnderwoodM@missouri.edu

${ }^{3}$ Centre Européen de Recherche et d'Enseignement des Géosciences de I'Environement, Aix-Marseille University, Europole de l'Arbois, 13545 Aix en Provence, France.

\section{Abstract}

This report documents the results of constant-flow permeability tests in the horizontal (cross-core) and vertical (along-core) directions, administered at an effective isotropic confining stress of $0.55 \mathrm{MPa}(80 \mathrm{psi})$. The whole-round specimens of mud(stone) were collected from depths of $\sim 34$ to 748 meters below seafloor at Integrated Ocean Drilling Program Sites C0011 and C0012 in the Shikoku Basin. Unfortunately, only ten samples were tested successfully; five samples failed because of drilling-induced core damage or friability. Most test results show minor anisotropy effects, with horizontal permeability greater than vertical. At Site C0011, the range of hydraulic conductivity $(K)$ is $1.76 \times 10^{-8}$ to $3.70 \times 10^{-10} \mathrm{~cm} / \mathrm{s}$. Intrinsic permeability $(k)$ ranges from $1.75 \times$ $10^{-17}$ to $3.67 \times 10^{-19} \mathrm{~m}^{2}$, and the average ratio of horizontal to vertical permeability $\left(k_{\mathrm{h}} / k_{\mathrm{v}}\right)$ is 1.26 . At Site C0012, values of $K$ range from $3.80 \times 10^{-8}$ to $1.69 \times 10^{-9} \mathrm{~cm} / \mathrm{s}$. Intrinsic permeability ranges from $3.77 \times 10^{-17}$ to $1.68 \times 10^{-18}$, and the average ratio of $k_{\mathrm{h}} / k_{\mathrm{v}}$ is 1.58 . Environmental scanning electron microscopy shows that grain fabric is random and does not vary significantly among the specimens tested. Moreover, the correlation of microfabric statistics with $k_{\mathrm{h}} / k_{\mathrm{v}}$ values is not statistically significant.

\section{Introduction}

The primary objective of Integrated Ocean Drilling Program (IODP) Expedition 322 was to document the characteristics of incoming sedimentary strata and uppermost igneous basement prior to their arrival at the subduction front of the Nankai Trough (see the "Expedition 322 summary" chapter [Underwood et al., 2010]). IODP Site C0011 is located seaward of the trench on the northwest flank of Kashinosaki Knoll in the Shikoku Basin (Fig. F1), whereas Site C0012 is located near the crest of the knoll. IODP Expedition 333 returned to both sites to core previously unsampled intervals, measure temperature, and collect additional basement material (see the "Expedition 333 summary" chapter [Expedition 333 Scientists, 2012a]).

Values of intrinsic permeability $(k)$ and hydraulic conductivity $(K)$ for natural clay-rich sediment and shale (e.g., Neuzil, 1994; Gamage et al., 2011) typically span several orders of magnitude. This is because hydrogeological properties of fine-grained sediments and sedimentary rocks depend on many factors, some of which are in- 
herited from the time of deposition. Grain size and shape, sorting, particle orientation, surface charges on clay particles, and fabric are important, as are the superimposed effects of burial diagenesis (e.g., Moon and Hurst, 1984; Bennett et al., 1989). Microfabric and permeability can be highly anisotropic, especially as the depth of burial increases and alignment of platy minerals becomes more uniform with respect to the orientation of maximum principal effective stress (e.g., Clennell et al., 1999; Kim et al., 1999; Bolton et al., 2000; Aplin et al., 2006). The anisotropy of permeability should follow changes in grain fabric as burial increases because pore fluids flow more easily along, rather than across, the longaxis direction of grain alignment. To quantify the hydrogeologic anisotropy of Shikoku Basin sediments, we compared horizontal (cross-core) permeability $\left(k_{\mathrm{h}}\right)$ and vertical (along-core) permeability $\left(k_{\mathrm{v}}\right)$ at the same sampling depths. These tests add to an extensive set of transect-wide hydrogeological data as part of the Nankai Trough Seismogenic Zone Experiment (e.g., Dugan and Daigle, 2011; Ekinci et al., 2011; Rowe et al., 2012; Yue et al., 2012; Dugan and Zhao, 2013; Screaton et al., 2013).

\section{Methods and materials}

\section{Sampling and sample handling}

The whole-round (WR) specimens that we tested from Sites C0011 and C0012 consist of hemipelagic mud and mudstone with varying degrees of consolidation. Sample depths range from 36 to 748 meters below seafloor (mbsf), with the distribution covering lithostratigraphic Units I through IV (Table T1). The dips of bedding surfaces relative to the horizontal plane (Fig. F2) are as steep as $63^{\circ}$, as shown by nearby measurements on split core (see the "Site C0011" and "Site C0012" chapters [Expedition 322 Scientists, 2010b, 2010c] and the "Site C0011" and "Site C0012" chapters [Expedition 333 Scientists, 2012b, 2012c]). The WR samples were capped and taped in their plastic core liners on board the $D / V$ Chikyu, sealed with wet sponges in aluminum vacuum bags to retard moisture loss, and stored at $\sim 4^{\circ} \mathrm{C}$ until immediately prior to trimming.

To extract each specimen, the plastic core liner was cut lengthwise along two lines $180^{\circ}$ apart using a hacksaw. Cylinders for tests in the vertical (alongcore) direction were trimmed using a wire saw and soil lathe. The length after trimming was $3.15-7.11 \mathrm{~cm}$ and averaged $5.78 \mathrm{~cm}$ (Table T1), as measured by caliper to a resolution of $0.03 \mathrm{~cm}$. The diameter was $3.67-6.54 \mathrm{~cm}$ and averaged $4.31 \mathrm{~cm}$. Whenever possible, a second cylinder for tests in the horizontal (cross-core) direction was trimmed to comparable di- mensions from material immediately below the cylinder for vertical flow. Unfortunately, most of the deeper WR specimens that were recovered by rotary core barrel (RCB) during Expedition 322 broke while trimming because of ubiquitous drilling-induced microcracks (Table T1). In other cases, the intact material was too sparse to trim two cylinders. One specimen (322-C0012A-17R-2) cracked during the test, which compromised results. Two samples (322C0011B-3R-4 and 322-C0012A-8R-3) could not be trimmed for a horizontal flow test because of fracturing. During Expedition 333, the hydraulic piston coring system (HPCS) and the extended punch coring system (EPCS) were deployed at shallower depths, which resulted in much better core quality. Sample 333-C0011D-32X-6, however, was too friable to trim.

For most samples, we calculated values of initial (pretest) and post-test porosity from measurements of gravimetric water content (Table T1). This was done by oven drying the trimmings at $105^{\circ} \mathrm{C}$ in accordance with shipboard protocols (see the "Methods" chapter [Expedition 322 Scientists, 2010a] and the "Methods" chapter [Expedition 333 Scientists, 2012a]) and by assuming 100\% pore water saturation. Values of grain density were imported from shipboard measurements of the closest adjacent specimen (see the "Site C0011" and "Site C0012" chapters [Expedition 322 Scientists, 2010b, 2010c] and the "Site C0011" and "Site C0012" chapters [Expedition 333 Scientists, 2012b, 2012c]). A correction for pore water salt content was applied using

$$
W_{\mathrm{c}}=\left(M_{\mathrm{t}}-M_{\mathrm{d}}\right) /\left(M_{\mathrm{d}}-r M_{\mathrm{t}}\right) \text {, }
$$

where

$$
\begin{aligned}
& W_{\mathrm{c}}=\text { corrected dry weight, } \\
& M_{\mathrm{t}}=\text { total mass of saturated specimen, } \\
& M_{\mathrm{d}}=\text { mass of dried specimen, and } \\
& r \quad=\text { salinity (permil) }
\end{aligned}
$$

For salt corrections on pretest trimmings, we assumed an average interstitial salinity value of $35 \%$; for post-test trimmings, we assumed a value of $25 \%$ to approximate the simulated seawater that was used to saturate specimens.

\section{Constant-flow apparatus}

Yue et al. (2012) provides a thorough description of the instrumentation and testing procedures for permeability at the University of Missouri (USA). To summarize, the system consists of an acrylic confining cell, a constant-flow syringe pump, one differential pressure transducer to measure hydraulic head difference between the specimen top cap and bottom cap, and an air/water interface panel for regulat- 
ing the confining fluid pressure and backpressure (Fig. F3). Signals from the differential pressure transducer permit calculations of hydraulic head difference $(\Delta h)$ at a precision of $\pm 1 \mathrm{~cm} \mathrm{H}_{2} \mathrm{O}$ over a range of $\pm 1000 \mathrm{~cm} \mathrm{H}_{2} \mathrm{O}$. A digital interface also records values of effective isotropic confining stress $\left(\sigma^{\prime}\right)$ and elapsed time. A syringe pump (KDS Scientific, Model 260) simultaneously injects and extracts pore fluid from opposite ends of the specimen. The flow pump holds one syringe (Hamilton GasTight Series 1000) to infuse pore fluid into one end, and another syringe withdraws an equal volume of fluid from the other end at the same rate. During the tests described here, volumetric flow rate $(Q)$ ranged from $3.0 \times 10^{-5}$ $\mathrm{cm}^{3} / \mathrm{min}$ to $1.0 \times 10^{-3} \mathrm{~cm}^{3} / \mathrm{min}$.

\section{Backpressure saturation}

Prior to our tests, all permeant lines and porous stones are saturated with simulated seawater (25 g $\mathrm{NaCl}$ to $1 \mathrm{~L}$ tap water). After placing a specimen on the pedestal, the top cap is attached, and a latex membrane is added to encase the cylinder using a vacuum membrane expander. The confining chamber is then sealed, and the cell is filled with tap water. Saturation is achieved by ramping pore-fluid backpressure to $0.48 \mathrm{MPa}$ (70 psi) using the panel board (air/water interface) while also ramping the confining pressure to maintain an effective isotropic confining stress of $0.034 \mathrm{MPa}$ (5 psi). The elevated backpressure is maintained for at least $24 \mathrm{~h}$. We confirm saturation by increasing the confining pressure to $0.55 \mathrm{MPa}(80 \mathrm{psi})$ and measuring the corresponding pore pressure $(u)$ response, which yields Skempton's $B$-value $(B=\Delta u / \Delta \sigma)$. Specimens are "saturated" if $B \geq$ 0.95 (Table T1) or if a $B$-value $<0.95$ remains constant for more than $48 \mathrm{~h}$. After saturation, the cell pressure is increased to consolidate the specimen at an isotropic effective stress of $0.55 \mathrm{MPa}$. Pore water drains during consolidation from both the top and bottom of the specimen by opening valves on the confining cell. The volume of expelled pore water is measured using the backpressure pipette and monitored for equilibrium to calculate the corresponding volume change of the specimen.

\section{Constant-flow tests}

We completed 10 successful constant-flow tests on cylinders trimmed parallel to the core axis and 8 tests on cylinders trimmed perpendicular to the core axis (Table T1). The ideal protocol consists of two tests from top to bottom (denoted subsequently as a negative flow value) and two tests bottom to top (denoted as a positive flow value) (Fig. F4). We monitor the transient response from the differential pressure transducer. Unfortunately, the pressure transducer behaved erratically during some of the tests, and after the necessary repairs were completed, those specimens had degraded too much to yield reliable replicate tests (Table T2). Plots of applied discharge velocity $(v)$ and steady-state hydraulic gradient $\left(i_{s}\right)$ allow for visual assessments of consistency and linearity (see the "Appendix"). For tests to be regarded as reliable, the coefficient of determination $\left(R^{2}\right)$, calculated by least-squares linear regression of those values, must be $>0.9835$.

\section{Data analysis}

We calculated the value of hydraulic conductivity $(K$, in units of $\mathrm{m} / \mathrm{s}$ ) for each specimen using Darcy's law:

$$
Q=K i_{s} A=K\left(\Delta h_{s} / \Delta L\right) A,
$$

where

$Q$ = applied volumetric flow rate $\left(\mathrm{cm}^{3} / \mathrm{s}\right)$,

$i_{\mathrm{s}}=$ steady-state hydraulic gradient,

$\Delta h_{\mathrm{s}}=$ steady-state head difference,

$\Delta L=$ length over which head difference occurs (initial height of the specimen), and

$A=$ cross-sectional flow area (initial specimen area).

The corresponding value of discharge velocity is computed using: $v=Q / A$. Conversion of hydraulic conductivity to values of intrinsic permeability $(k$, in units of $\mathrm{m}^{2}$ ) takes the permeant properties into account:

$$
k=(K \mu) /(\rho g),
$$

where

$$
\begin{aligned}
& \mu=\text { viscosity of permeant at room temperature } \\
& \quad(0.001 \mathrm{~Pa} \cdot \mathrm{s}), \\
& \rho=\text { density of permeant }\left(1027 \mathrm{~kg} / \mathrm{m}^{3}\right), \text { and } \\
& g=\text { gravitational acceleration }\left(9.81 \mathrm{~m} / \mathrm{s}^{2}\right) .
\end{aligned}
$$

\section{Imaging microfabric}

Yue et al. (2012) provides a thorough description of the procedures used at the University of Missouri (USA) to image and characterize microfabric. To summarize, a razor blade is used to cut oriented specimens while trimming cylinders for the vertical and horizontal flow-through tests (Fig. F5). Wet, uncoated, and unfixed surfaces are imaged using an FEI Quanta 600 FEG scanning electron microscope (SEM), which operates in environmental mode (ESEM) at $30 \mathrm{kV}$ with the specimen chamber pressure set at $700 \mathrm{~Pa}$. Water vapor ( 98\% humidity) from a built-in reservoir keeps specimens from losing moisture with the cooling stage set to $2^{\circ} \mathrm{C}$. We use a gaseous backscattered electron detector, spot $=3.0$, and 
a working distance of $\sim 10 \mathrm{~mm}$. This combination generates an imaging resolution of $\sim 4 \mathrm{~nm}$, and dimensions of the field of view are $\sim 145 \times 130 \mu \mathrm{m}$ at 2000× magnification (Fig. F6).

The gray mode TIF images from ESEM are processed using "ImageJ" software (rsbweb.nih.gov/ij/index.html), which isolates the apparent dimensions of objects in a 2-D image. We generally count between 100 and 500 grains per image (depending on particle size) to calculate statistics for preferred grain orientation (Table T3). Each particle orientation (azimuth of the apparent long axis) is assigned to an angle between $0^{\circ}$ and $180^{\circ}$. For the vertical cut surface, the core axis is oriented at $90^{\circ}$. Rose diagrams were constructed using "Rozeta" software (www.softpedia.com/get/Science-CAD/Rozeta.shtml), which automatically assigns azimuths to bins at $10^{\circ}$ intervals. Cumulative frequency curves are then used to obtain graphical solutions of standard deviation $(d)$ according to Folk and Ward (1957) statistics:

$$
d=\left[\left(\phi_{84}-\phi_{16}\right) / 4\right]+\left[\left(\phi_{95}-\phi_{5}\right) / 6.6\right],
$$

where $\phi_{84}, \phi_{16}, \phi_{95}$, and $\phi_{5}$ represent the azimuth (in degrees) at the eighty-fourth, sixteenth, ninety-fifth, and fifth percentiles. In this context, the largest possible value of $d$ is $72.3^{\circ}$ (i.e., a case in which $\phi_{16}$ and $\phi_{5}=$ $0^{\circ}$ and $\phi_{84}$ and $\left.\phi_{95}=180^{\circ}\right)$. To compare each standard deviation to this maximum $d$ value we calculate the "index of microfabric orientation":

$$
i=1-(d / 72.3) \text {. }
$$

With random arrangements of particles, the cumulative curve is relatively flat (slope $<0.75$ ) near the median, the value of $d$ is $>35^{\circ}$, and $i$ is $<0.5$. As particles attain better parallel alignment, azimuths cluster more tightly, the slope of the cumulative curve steepens (slope $>1.00$ ) near the median, the value of $d$ is $<25^{\circ}$, and $i$ is $>0.65$ (Yue et al., 2012). The ratio of $i_{\mathrm{h}}$ to $i_{\mathrm{v}}$ permits quantitative comparison of imaging surfaces that were cut parallel and perpendicular to the core axis and allows for numerical comparisons with the anisotropy of permeability.

We tried a second method to quantify microfabric more rigorously by calculating the mean angle $(\alpha)$ of the angular distribution with $180^{\circ}$-periodic circular statistics (Fisher, 1995; Berens, 2009). First, the mean resultant vector is calculated from the summation of unit vectors representing particle orientation. The distribution of particle orientation is $180^{\circ}$-periodic, so the angle of the unit vector is twice the angle measured on the particle and, hence, the mean angle $\alpha$ is half the angle of the mean resultant vector. The resultant vector length $R$ is between 0 and 1 and con- stitutes a proxy for the directionality of the distribution; a value of 0 coincides with a uniform angular distribution, and a perfectly aligned distribution results in a value of 1 . The probability that data reflect a uniform distribution of orientation (p-value) is then estimated from the Rayleigh test (Fisher, 1995; Berens, 2009). The mean angle $\alpha$ is considered significant only if the p-value is less than 0.05. Use of this statistical approach appears generally optimistic because few images display a clear fabric based upon visual assessment. We recognized weak preferred orientations on vertical sections of two samples: 333C0012D-9H-3, $120 \mathrm{~cm}$, which displays subhorizontal bedding and a mean angle of $166^{\circ}(\mathrm{p}=0.00341)$, and 333-C0012C-9H-7, $51 \mathrm{~cm}$, which displays steeper bedding dips and a mean angle of $53^{\circ}(\mathrm{p}=0.0431)$.

\section{Results}

Table T1 summarizes values of water content and porosity for trimmings measured before and after each flow-through test. In some cases, water content decreased relative to shipboard values, and those discrepancies probably were caused by escape of moisture during shipment and storage of the WR specimens. For two specimens (322-C0012A-8R-3 and 333-C0011D-49X-5), values of porosity increased after the flow-through test. That perturbation was probably caused by expansion of waterfilled microcracks after the confining pressure of $0.55 \mathrm{MPa}$ was released. Each individual test result is illustrated in the "Appendix." Table T2 shows values of volumetric flow rate, discharge velocity, steadystate head loss, steady-state hydraulic gradient, hydraulic conductivity, and intrinsic permeability for each test. Table T4 summarizes the average values of permeability for each horizontal and vertical specimen and the corresponding $k_{\mathrm{h}} / k_{v}$ ratio.

As also noted by Dugan and Zhao (2013), drilling and coring disturbance was both extensive and severe during Expedition 322. Consequently, permeability values for those cores should be interpreted with caution, essentially serving as upper limits on in situ permeability. At Site C0011 (flank of Kashinosaki Knoll), the highest value of vertical hydraulic conductivity $\left(K_{\mathrm{v}}\right)$ is $1.31 \times 10^{-8} \mathrm{~cm} / \mathrm{s}$, with $k=1.31 \times$ $10^{-17} \mathrm{~m}^{2}$. The lowest value of $K_{\mathrm{v}}$ is $3.70 \times 10^{-10} \mathrm{~cm} / \mathrm{s}$, with $k_{\mathrm{v}}=3.67 \times 10^{-19} \mathrm{~m}^{2}$. The highest value of horizontal hydraulic conductivity $\left(K_{\mathrm{h}}\right)$ is $1.76 \times 10^{-8} \mathrm{~cm} / \mathrm{s}$, with $k_{\mathrm{h}}=1.75 \times 10^{-17} \mathrm{~m}^{2}$. The lowest value of $K_{\mathrm{h}}$ is $5.06 \times 10^{-10} \mathrm{~cm} / \mathrm{s}$, with $k_{\mathrm{h}}=5.02 \times 10^{-19}$. The ratio $k_{\mathrm{h}} / k_{\mathrm{v}}$ is generally close to 1.0 , ranging from 0.87 to 1.78 and averaging 1.26. Sample 322-C0011B-3R-4 yielded unusually inconsistent results for the four 
replicate tests (Table T2); its average permeability value is significantly greater than averages for nearby Sample 333-C0011D-49X-5 (Table T4), and that scatter may also be a symptom of coring damage.

At Site C0012 (crest of Kashinosaki Knoll), the highest value of $K_{\mathrm{v}}$ is $3.25 \times 10^{-8} \mathrm{~cm} / \mathrm{s}$, with a corresponding $k_{\mathrm{v}}$ of $3.23 \times 10^{-17} \mathrm{~m}^{2}$. The lowest value of vertical $K_{\mathrm{v}}$ is $1.69 \times 10^{-9} \mathrm{~cm} / \mathrm{s}$, with $k_{\mathrm{v}}=1.68 \times 10^{-18} \mathrm{~m}^{2}$. The highest value of $K_{\mathrm{h}}$ is $1.76 \times 10^{-8} \mathrm{~cm} / \mathrm{s}$, with $k_{\mathrm{h}}=1.75$ $\times 10^{-17} \mathrm{~m}^{2}$. The lowest value of $K_{\mathrm{h}}$ is $5.06 \times 10^{-10} \mathrm{~cm} / \mathrm{s}$, with $k_{\mathrm{h}}=5.02 \times 10^{-19} \mathrm{~m}^{2}$. The $k_{\mathrm{h}} / k_{\mathrm{v}}$ ratio is generally close to 1.0 , ranging from 0.87 to 2.82 and averaging 1.57. The largest amount of anisotropy occurs in a sample from an interval of slumping, where bedding dips are $\sim 60^{\circ}$.

Figure F7 illustrates how values of vertical and horizontal permeability change with depth of burial. The range of values is consistent with the test results of Dugan and Zhao (2013) and Screaton et al. (2013) over comparable depth intervals. For the most part, values of both vertical and horizontal permeability decrease with depth, but the anisotropy of permeability remains close to 1 . Figure $\mathbf{F 8}$ displays the relation between permeability and porosity at an effective confining stress of $0.55 \mathrm{MPa}$. As expected, the test results show a systematic decrease in permeability as porosity decreases.

Figure F9 catalogs the rose diagrams of particle orientation and corresponding values for the standard deviation, index of orientation, mean angle, and resultant vector length (see Table T3 for microfabric statistics). The cumulative frequency curves are plotted on Figure F10. The standard deviation for grain orientation ranges from $48.6^{\circ}$ to $62.5^{\circ}$, and the index of orientation ranges from 0.14 to 0.33 . The mean angle ranges from $8.77^{\circ}$ to $178.11^{\circ}$, and the resultant vector length ranges from 0.055 to 0.220 . All such values are consistent with random arrangements of particles. Ratios of $i_{\mathrm{h}} / i_{\mathrm{v}}$ range from $\sim 0.87$ to 2.82 . For the majority of specimens, microfabric on the vertical cut face shows better preferred orientation than microfabric on the horizontal cut (i.e., $i_{\mathrm{h}}<i_{\mathrm{v}}$ ). No trend is apparent between the indexes of orientation and depth of burial (Fig. F11). Similarly, we see no meaningful trend in $k_{\mathrm{h}} / k_{\mathrm{v}}$ vs. depth (Fig. F11). Linear regression shows that the relation between permeability anisotropy and $i$ values is not statistically significant. Samples with higher anisotropy of permeability $\left(k_{h} / k_{v}>1\right)$ tend to display better grain alignment on the vertical cut face, but the correlation coefficient is only 0.167 for the regression between $k_{\mathrm{h}} / k_{\mathrm{v}}$ and $i_{\mathrm{h}} / i_{\mathrm{v}}$. We surmise that enhanced grain alignment probably affects permeability more as compaction progresses below the range of our sampling.

\section{Acknowledgments}

Samples were provided by the Integrated Ocean Drilling Program (IODP). We thank the Mantle Quest Japan crew, Marine Works Japan technicians, and shipboard scientists aboard $D / V$ Chikyu for their assistance in acquisition of samples during Expeditions 322 and 333. Research at the University of Missouri was supported by Turkish Petroleum Cooperation (scholarship to Ekinci), the National Science Foundation (grant OCE-0751819 to Underwood), and the Consortium for Ocean Leadership (T322A58 and T333A58 to Underwood). Junhua Guo assisted with the procedures for fabric analysis.

\section{References}

Berens, P., 2009. CircStat: a MATLAB toolbox for circular statistics. J. Stat. Software, 31(10):1-21.http:// www.jstatsoft.org/v31/i10

Bennett, R.H., Fischer, K.M., Lavoie, D.L., Bryant, W.R., and Rezak, R., 1989. Porometry and fabric of marine clay and carbonate sediments: determinants of permeability. Mar. Geol., 89(1-2):127-152. doi:10.1016/00253227(89)90030-3

Bolton, A.J., Maltman, A.J., and Fisher, Q., 2000. Anisotropic permeability and bimodal pore-size distributions of fine-grained marine sediments. Mar. Pet. Geol., 17(6):657-672. doi:10.1016/S0264-8172(00)00019-2

Clennell, M.B., Dewhurst, D.N., Brown, K.M., and Westbrook, G.K., 1999. Permeability anisotropy of consolidated clays. In Aplin, A.C., Fleet, A.J., and MacQuaker, J.H.S. (Eds.), Muds and Mudstones: Physical and Fluid-Flow Properties. Geol. Soc. Spec. Publ., 158(1):79-96. doi:10.1144/GSL.SP.1999.158.01.07

Dugan, B., and Daigle, H., 2011. Data report: permeability, compressibility, stress state, and grain size of shallow sediments from Sites C0004, C0006, C0007, and C0008 of the Nankai accretionary complex. In Kinoshita, M., Tobin, H., Ashi, J., Kimura, G., Lallemant, S., Screaton, E.J., Curewitz, D., Masago, H., Moe, K.T., and the Expedition 314/315/316 Scientists, Proc. IODP, 314/315/316: Tokyo (Integrated Ocean Drilling Program Management International, Inc.). doi:10.2204/ iodp.proc.314315316.208.2011

Dugan, B., and Zhao, X., 2013. Data report: permeability of sediments from Sites C0011 and C0012, NanTroSEIZE Stage 2: subduction inputs. In Saito, S., Underwood, M.B., Kubo, Y., and the Expedition 322 Scientists, Proc. IODP, 322: Tokyo (Integrated Ocean Drilling Program Management International, Inc.). doi:10.2204/ iodp.proc.322.208.2013

Ekinci, M.K., Likos, W.J., Underwood, M.B., and Guo, J., 2011. Data report: permeability of mud(stone) samples 
from IODP Sites C0006 and C0007, Nankai Trough Seismogenic Zone Experiment. In Kinoshita, M., Tobin, H., Ashi, J., Kimura, G., Lallemant, S., Screaton, E.J., Curewitz, D., Masago, H., Moe, K.T., and the Expedition 314/ 315/316 Scientists, Proc. IODP, 314/315/316: Washington, DC (Integrated Ocean Drilling Program Management International, Inc.). doi:10.2204/

iodp.proc.314315316.214.2011

Expedition 322 Scientists, 2010a. Methods. In Saito, S., Underwood, M.B., Kubo, Y., and the Expedition 322 Scientists, Proc. IODP, 322: Tokyo (Integrated Ocean Drilling Program Management International, Inc.). doi:10.2204/iodp.proc.322.102.2010

Expedition 322 Scientists, 2010b. Site C0011. In Saito, S., Underwood, M.B., Kubo, Y., and the Expedition 322 Scientists, Proc. IODP, 322: Tokyo (Integrated Ocean Drilling Program Management International, Inc.). doi:10.2204/iodp.proc.322.103.2010

Expedition 322 Scientists, 2010c. Site C0012. In Saito, S., Underwood, M.B., Kubo, Y., and the Expedition 322 Scientists, Proc. IODP, 322: Tokyo (Integrated Ocean Drilling Program Management International, Inc.). doi:10.2204/iodp.proc.322.104.2010

Expedition 333 Scientists, 2012a. Expedition 333 summary. In Henry, P., Kanamatsu, T., Moe, K., and the Expedition 333 Scientists, Proc. IODP, 333: Tokyo (Integrated Ocean Drilling Program Management International, Inc.). doi:10.2204/iodp.proc.333.101.2012

Expedition 333 Scientists, 2012b. Methods. In Henry, P., Kanamatsu, T., Moe, K., and the Expedition 333 Scientists, Proc. IODP, 333: Tokyo (Integrated Ocean Drilling Program Management International, Inc.). doi:10.2204/iodp.proc.333.102.2012

Expedition 333 Scientists, 2012c. Site C0011. In Henry, P., Kanamatsu, T., Moe, K., and the Expedition 333 Scientists, Proc. IODP, 333: Tokyo (Integrated Ocean Drilling Program Management International, Inc.). doi:10.2204/iodp.proc.333.104.2012

Expedition 333 Scientists, 2012d. Site C0012. In Henry, P., Kanamatsu, T., Moe, K., and the Expedition 333 Scientists, Proc. IODP, 333: Tokyo (Integrated Ocean Drilling Program Management International, Inc.). doi:10.2204/iodp.proc.333.105.2012

Fisher, N.I., 1995. Statistical Analysis of Circular Data: New York (Cambridge Univ.y Press).

Folk, R.L., and Ward, W.C., 1957. Brazos River bar [Texas]: a study in the significance of grain size parameters. $J$. Sediment. Res., 27(1):3-26. http://jsedres.sepmonline.org/cgi/content/abstract/27/1/3
Gamage, K., Screaton, E., Bekins, B., and Aiello, I., 2011. Permeability-porosity relationships of subduction zone sediments. Mar. Geol., 279(1-4):19-36. doi:10.1016/ j.margeo.2010.10.010

Kim, J.-W., Bryant, W.R., Watkins, J.S., and Tieh, T.T., 1999. Electron microscopic observations of shale diagenesis, offshore Louisiana, USA, Gulf of Mexico. Geo-Mar. Lett., 18(3):234-240. doi:10.1007/s003670050073

Moon, C.F., and Hurst, C.W., 1984. Fabrics of muds and shales: an overview. In Stow, D.A.V., and Piper, D.J.W. (Eds.), Fine-Grained Sediments: Deep-Water Processes and Facies. Geol. Soc. Spec. Publ., 15(1):579-593. doi:10.1144/GSL.SP.1984.015.01.36

Neuzil, C.E., 1994. How permeable are clays and shales? Water Resour. Res., 30(2):145-150. doi:10.1029/ 93WR02930

Rowe, K.T., Screaton, E.J., and Ge, S., 2012. Coupled fluid flow and deformation modeling of the frontal thrust region of the Kumano Basin transect, Japan: implications for fluid pressures and décollement downstepping. Geochem., Geophys., Geosyst., 13:Q0AD23. doi:10.1029/2011GC003861

Screaton, E., Rowe, K., Sutton, J., and Atalan, G., 2013. Data report: permeabilities of Expedition 322 and 333 sediments from offshore the Kii Peninsula, Japan. In Saito, S., Underwood, M.B., Kubo, Y., and the Expedition 322 Scientists, Proc. IODP, 322: Tokyo (Integrated Ocean Drilling Program Management International, Inc.). doi:10.2204/iodp.proc.322.210.2013

Underwood, M.B., Saito, S., Kubo, Y., and the Expedition 322 Scientists, 2010. Expedition 322 summary. In Saito, S., Underwood, M.B., Kubo, Y., and the Expedition 322 Scientists, Proc. IODP, 322: Tokyo (Integrated Ocean Drilling Program Management International, Inc.). doi:10.2204/iodp.proc.322.101.2010

Yue, L., Likos, W.J., Guo, J., and Underwood, M.B., 2012. Data report: permeability of mud(stone) samples from Site C0001, IODP Expedition 315, Nankai Trough: NanTroSEIZE Stage 1. In Kinoshita, M., Tobin, H., Ashi, J., Kimura, G., Lallemant, S., Screaton, E.J., Curewitz, D., Masago, H., Moe, K.T., and the Expedition 314/315/316 Scientists, Proc. IODP, 314/315/316: Washington, DC (Integrated Ocean Drilling Program Management International, Inc.). doi:10.2204/ iodp.proc.3314315316.204.2012

Initial receipt: 11 November 2013

Acceptance: 4 February 2015

Publication: 6 April 2015

MS 322-211 
Figure F1. Map of NanTroSEIZE study area with locations of Sites C0011 and C0012 (modified from Expedition 333 Scientists, 2012a). White dots = other drill sites along the Kumano transect.

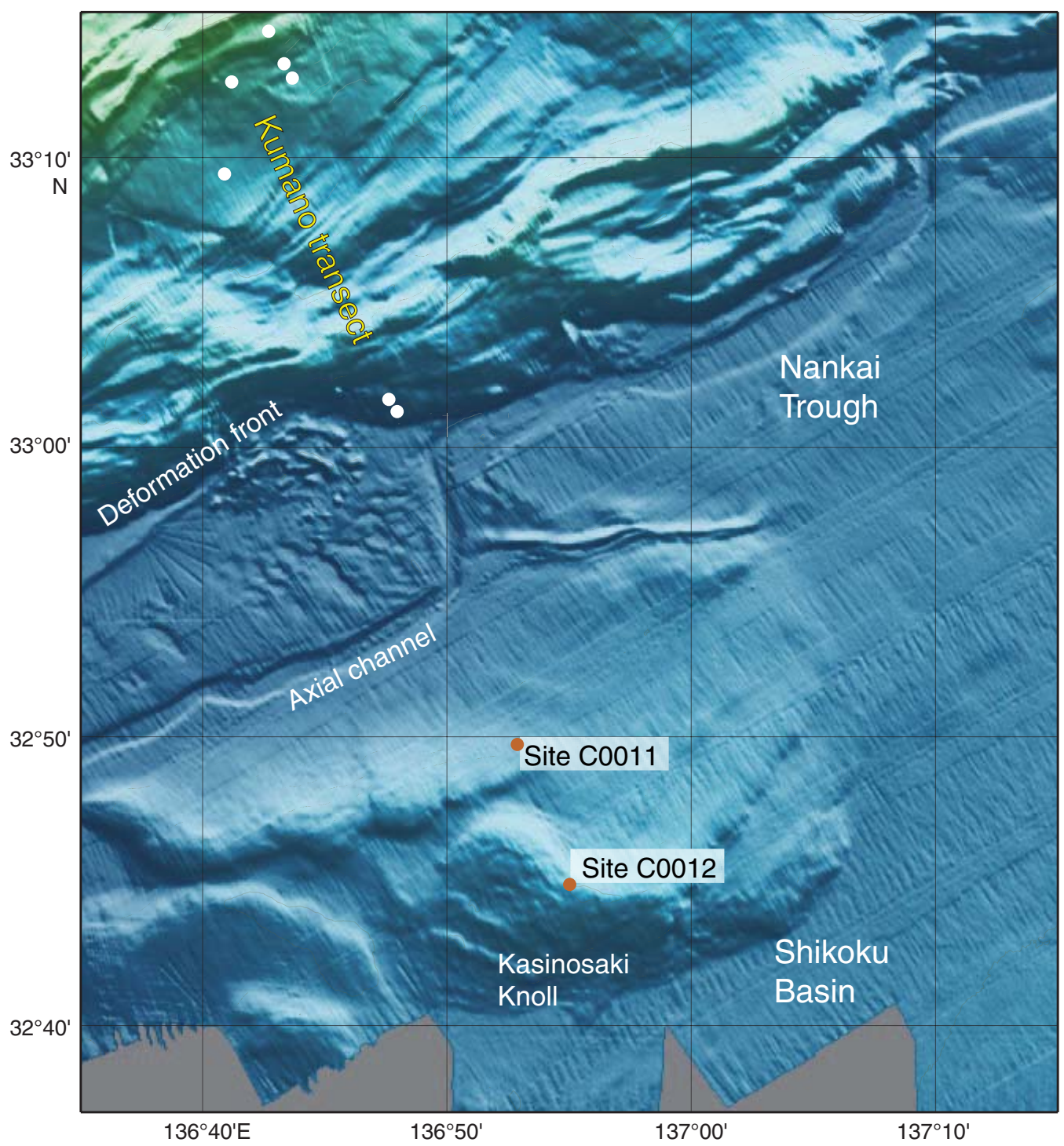


Figure F2. Stratigraphic columns and lithologic units for Sites C0011 and C0012, with positions of samples used for permeability tests. Red dots $=$ successful tests, yellow dots $=$ specimens that failed during trimming or testing. Bedding dips for closest nearby intervals are as previously reported (Expedition 322 Scientists, 2010b, 2010c; Expedition 333 Scientists, 2012c, 2012d).

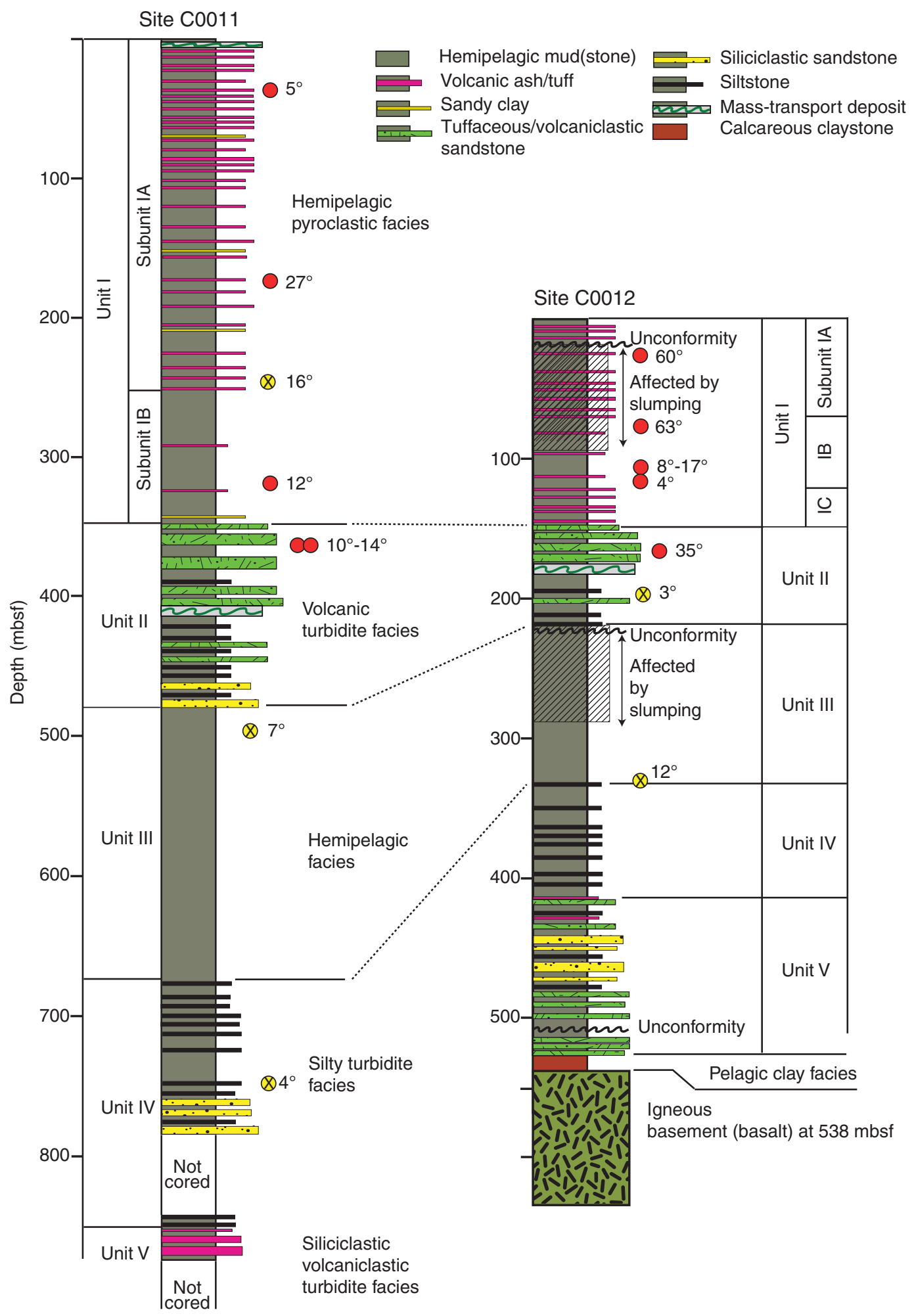


Figure F3. Schematic of testing system for constant-flow permeability at the University of Missouri (USA).

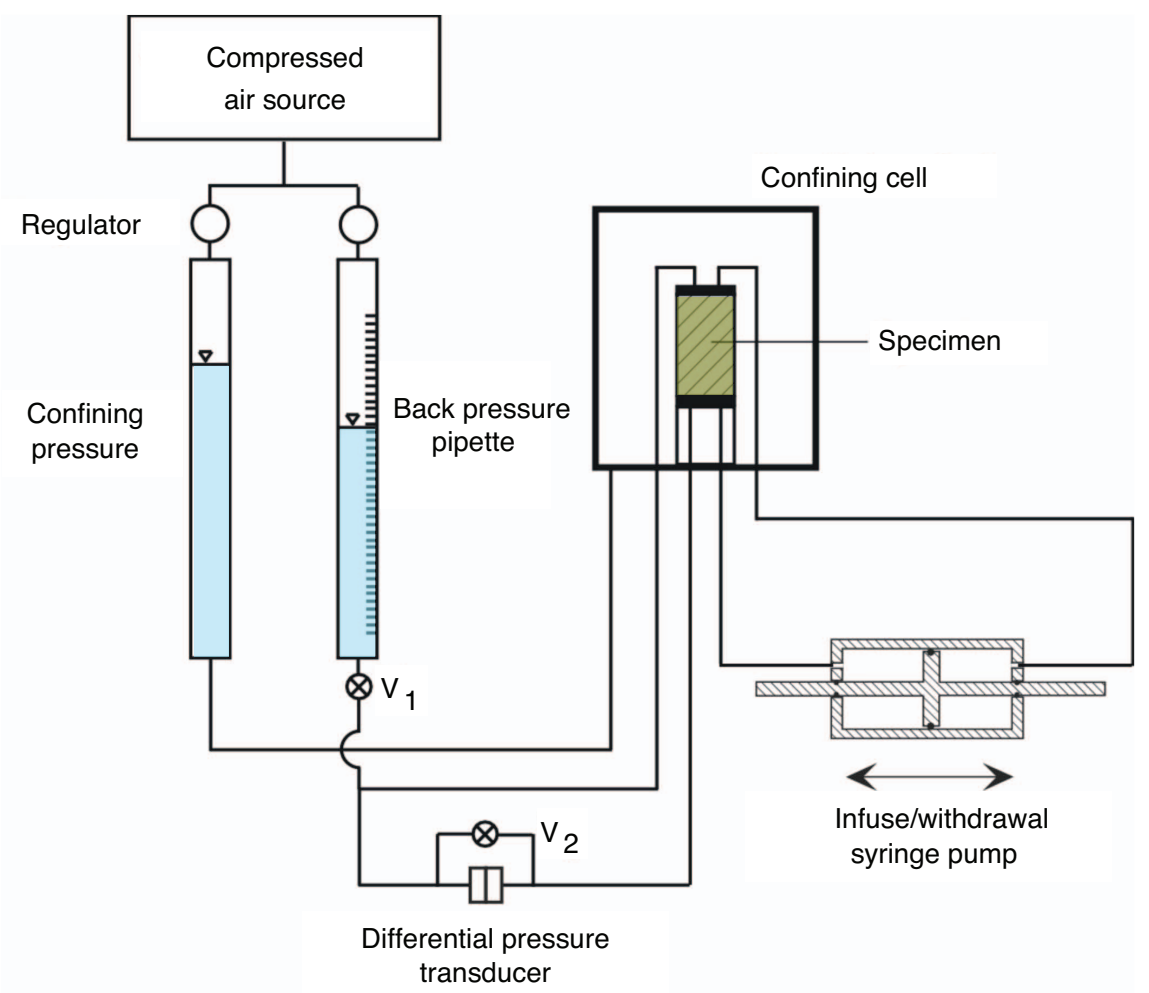


Figure F4. Example of typical responses of transient head difference $\left(\Delta h_{\mathrm{s}}\right)$ during flow-through testing. $Q=$ volumetric flow rate, $K=$ hydraulic conductivity.

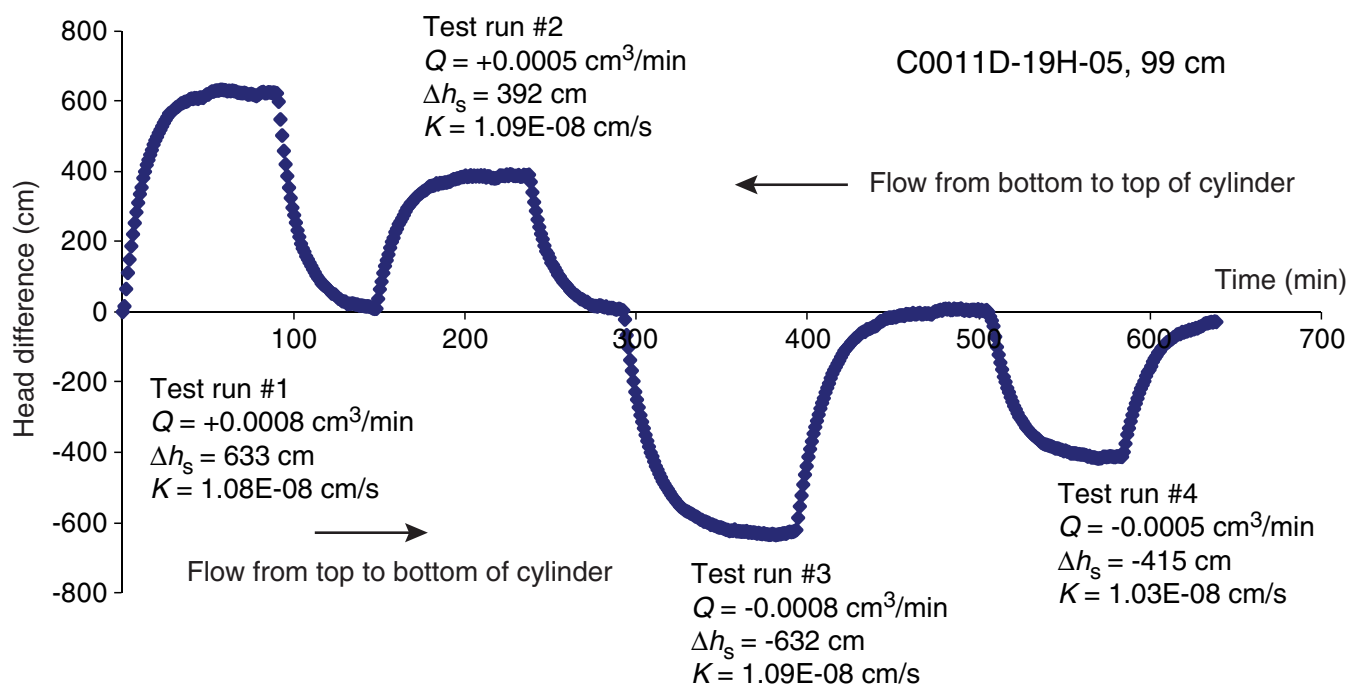


Figure F5. Geometric relations among bedding, orientation of the core axis, and the horizontal and vertical sections used for imaging by environmental scanning electron microscope.

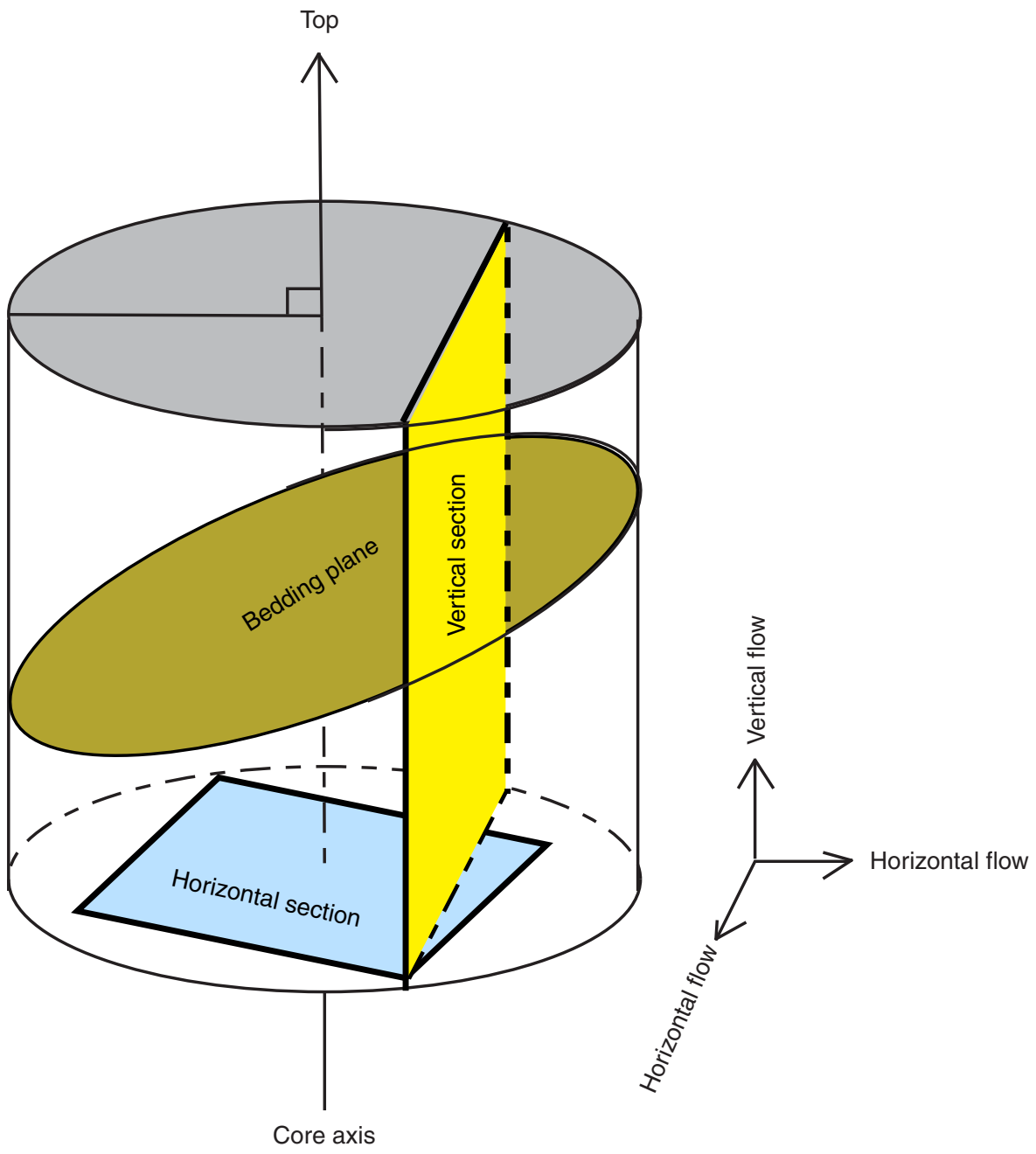


Figure F6. Environmental scanning electron microscope images for all specimens tested for permeability, Sites C0011 and C0012. Relative to the core axis, sections were cut parallel (vertical) and perpendicular (horizontal). See Figure F2 and Table T1 for bedding dips. (Continued on next two pages.)
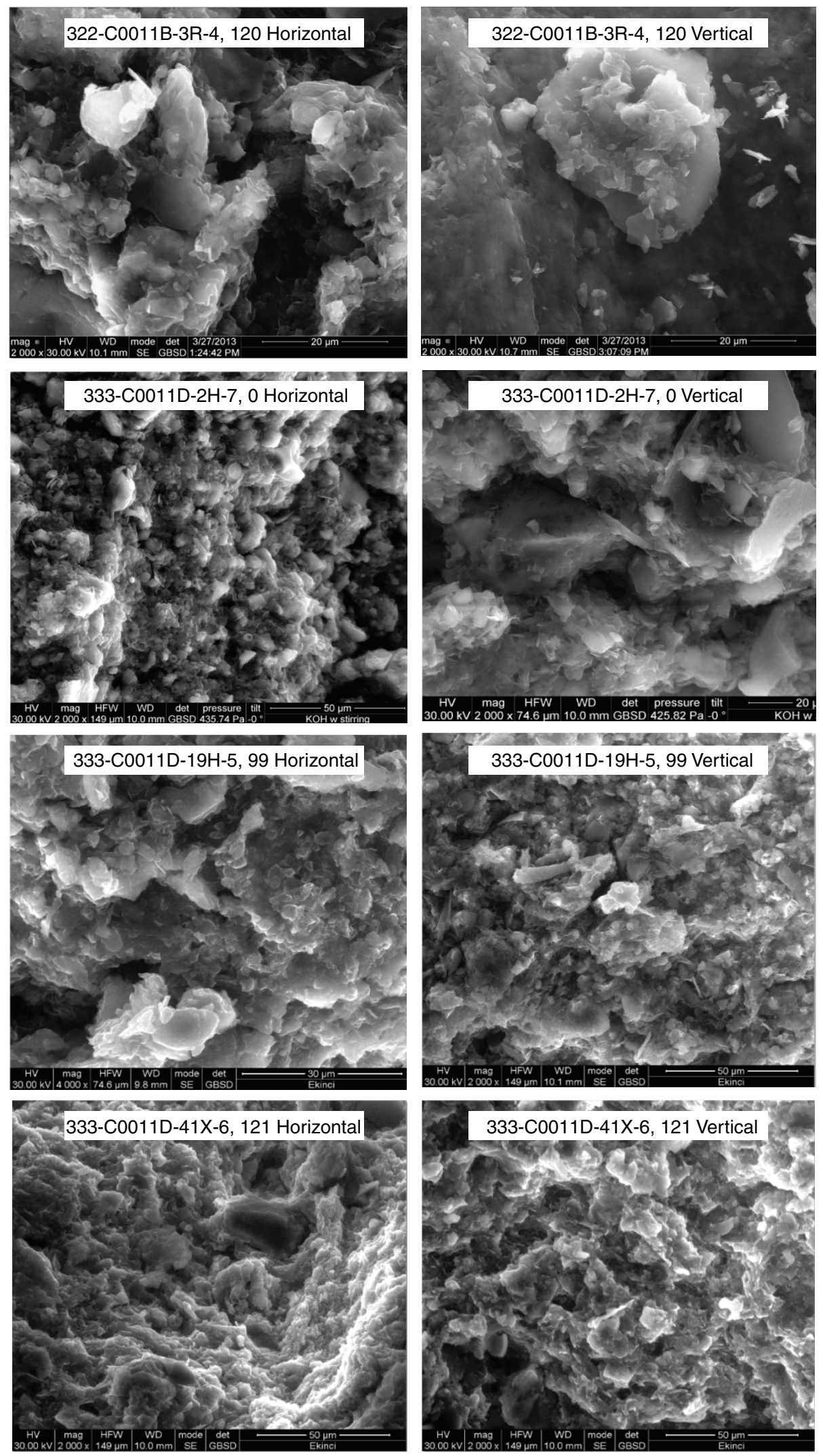
Figure F6 (continued). (Continued on next page.)
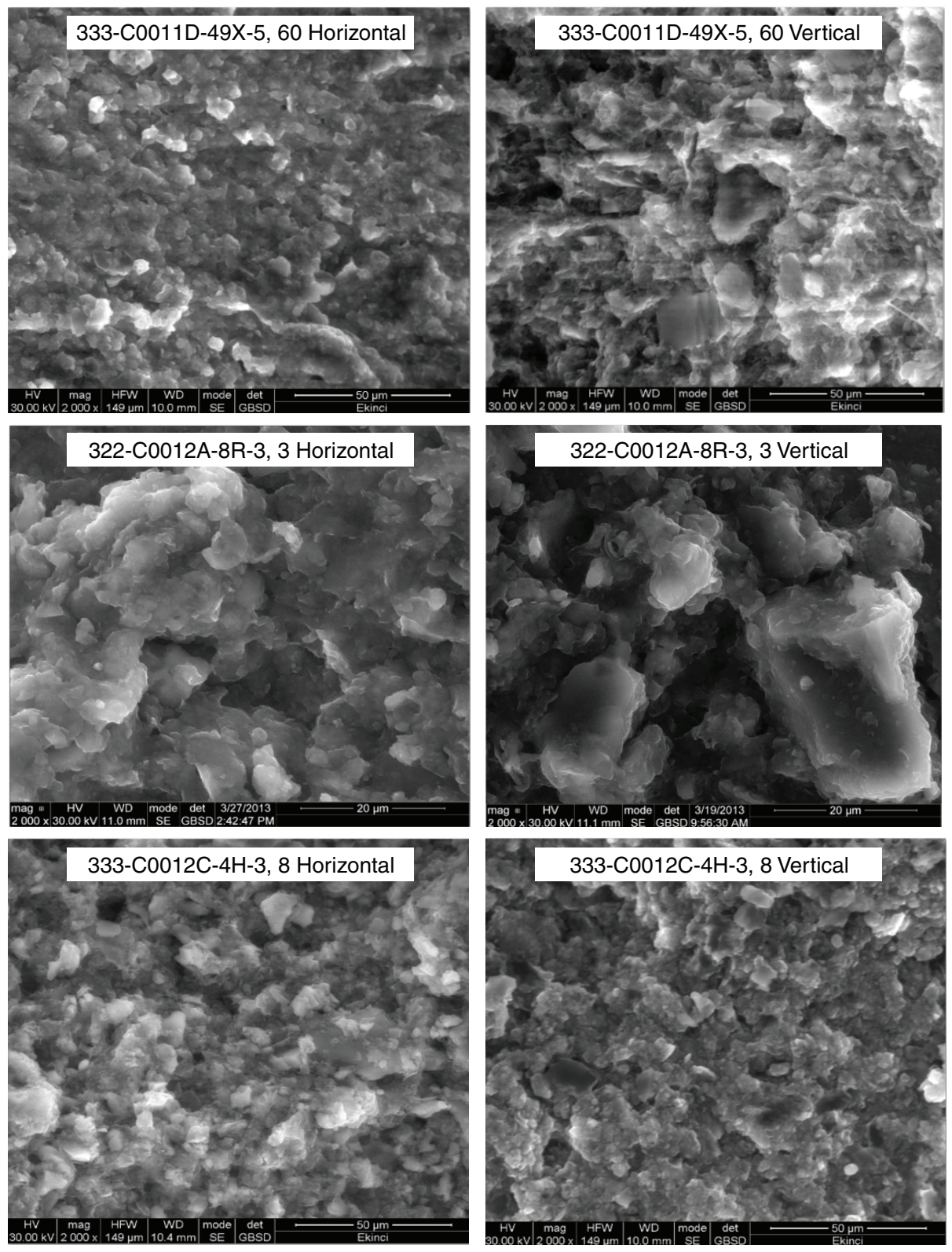
Figure F6 (continued).
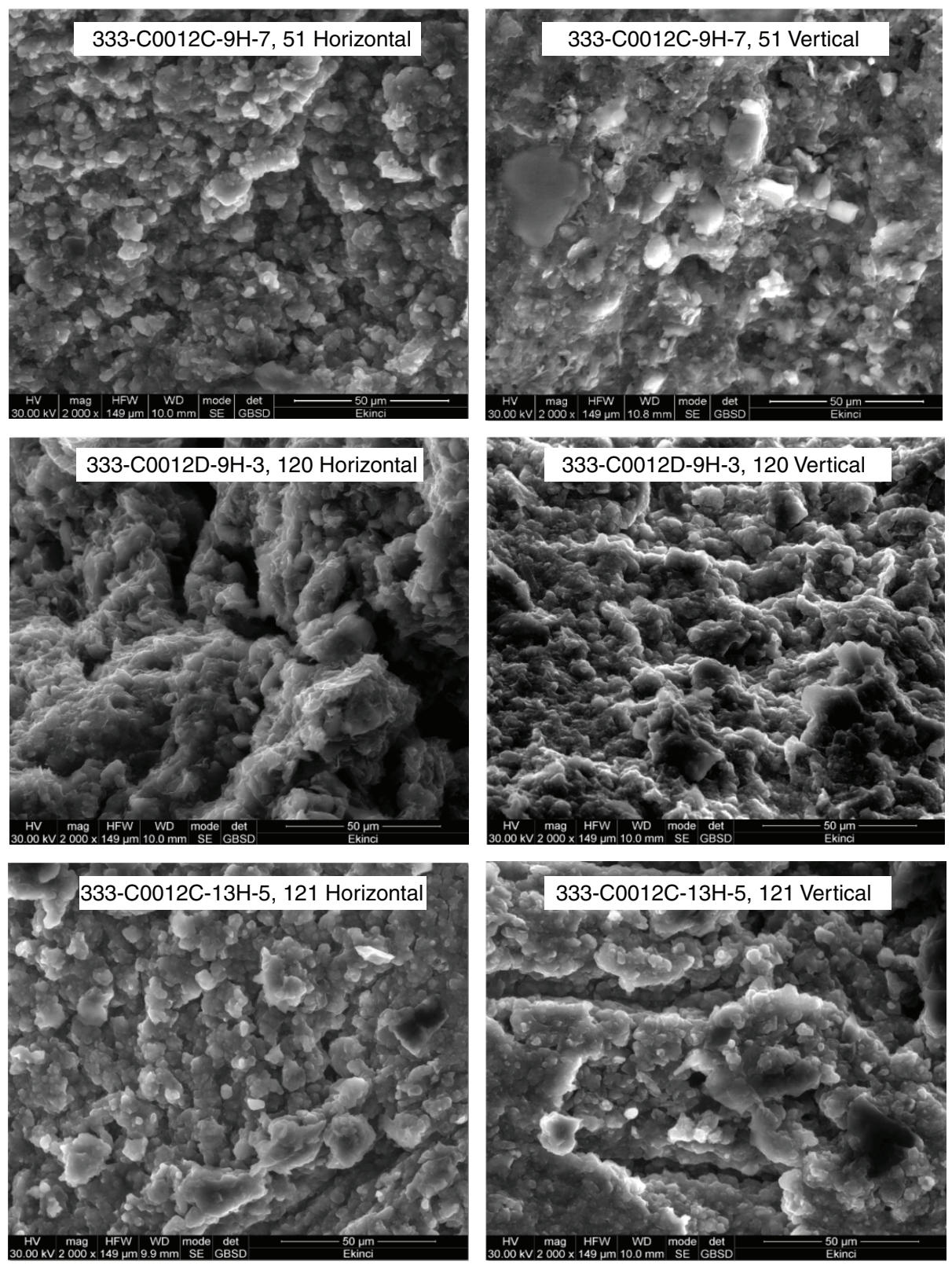
Figure F7. Values of intrinsic permeability (horizontal, vertical) vs. depth, Sites C0011 and C0012. Permeability was measured at an effective stress of $0.55 \mathrm{MPa}$.

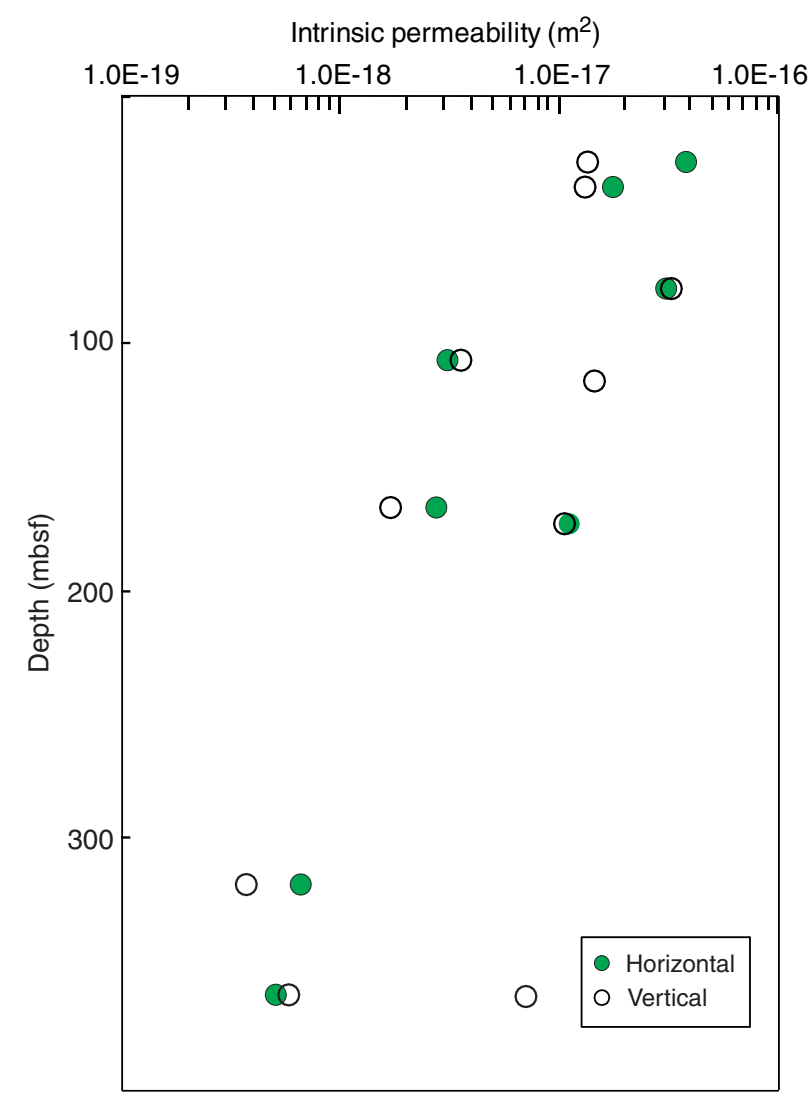


Figure F8. Relation between intrinsic permeability and post-test porosity for specimens, Sites C0011 and C0012.

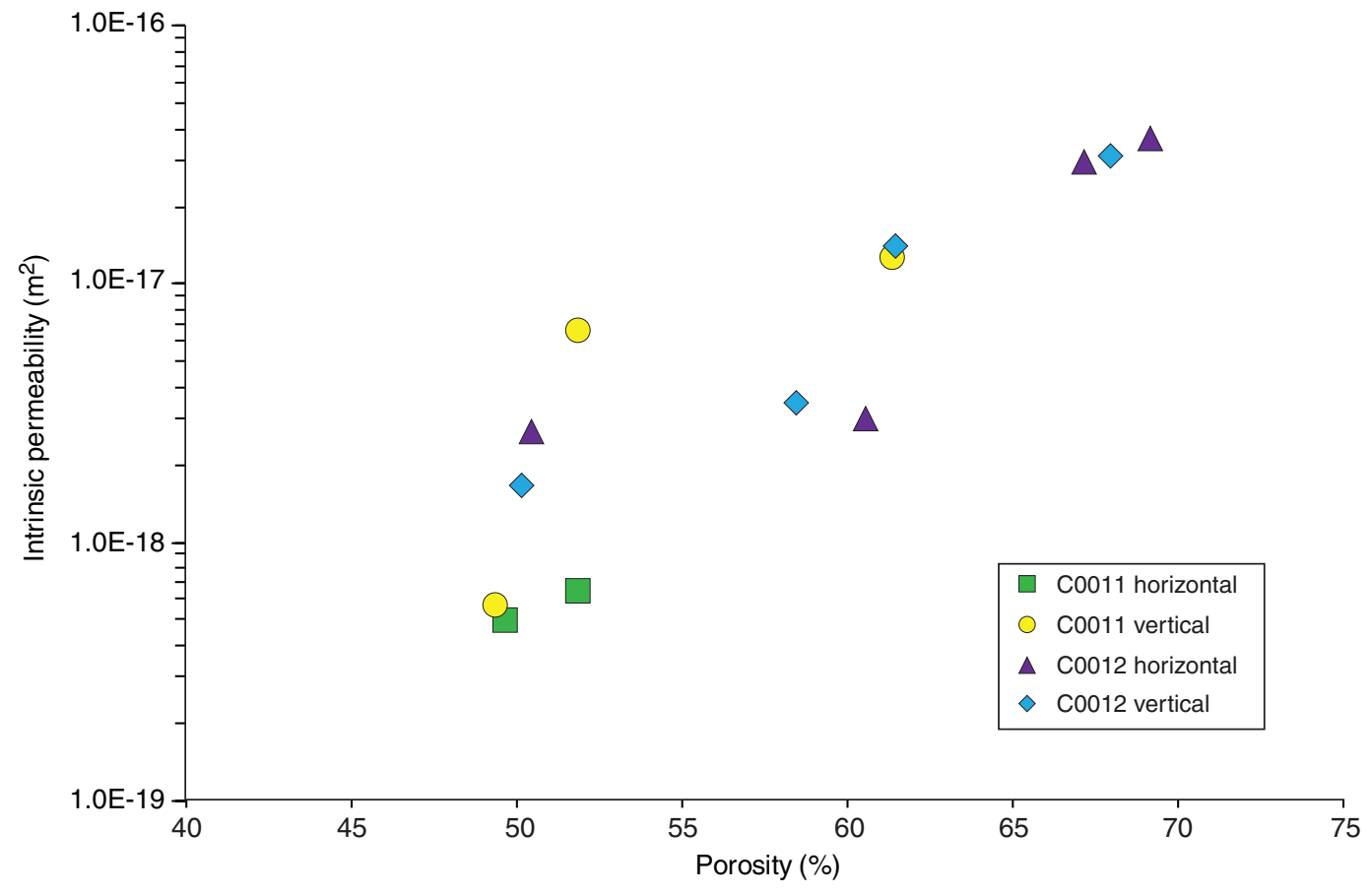


Figure F9. Orientation of grains (apparent long axis) measured on environmental scanning electron microscope (ESEM) images. Relative to the core axis, sections were cut parallel (vertical) and perpendicular (horizontal). See Figure F6 for the corresponding ESEM images. Also shown are values of standard deviation $(d)$ for grain orientation, values of microfabric orientation index $(i)$, values of resultant vector length $(R)$, and the mean angle $(\alpha)$ of the angular distribution. (Continued on next page.)
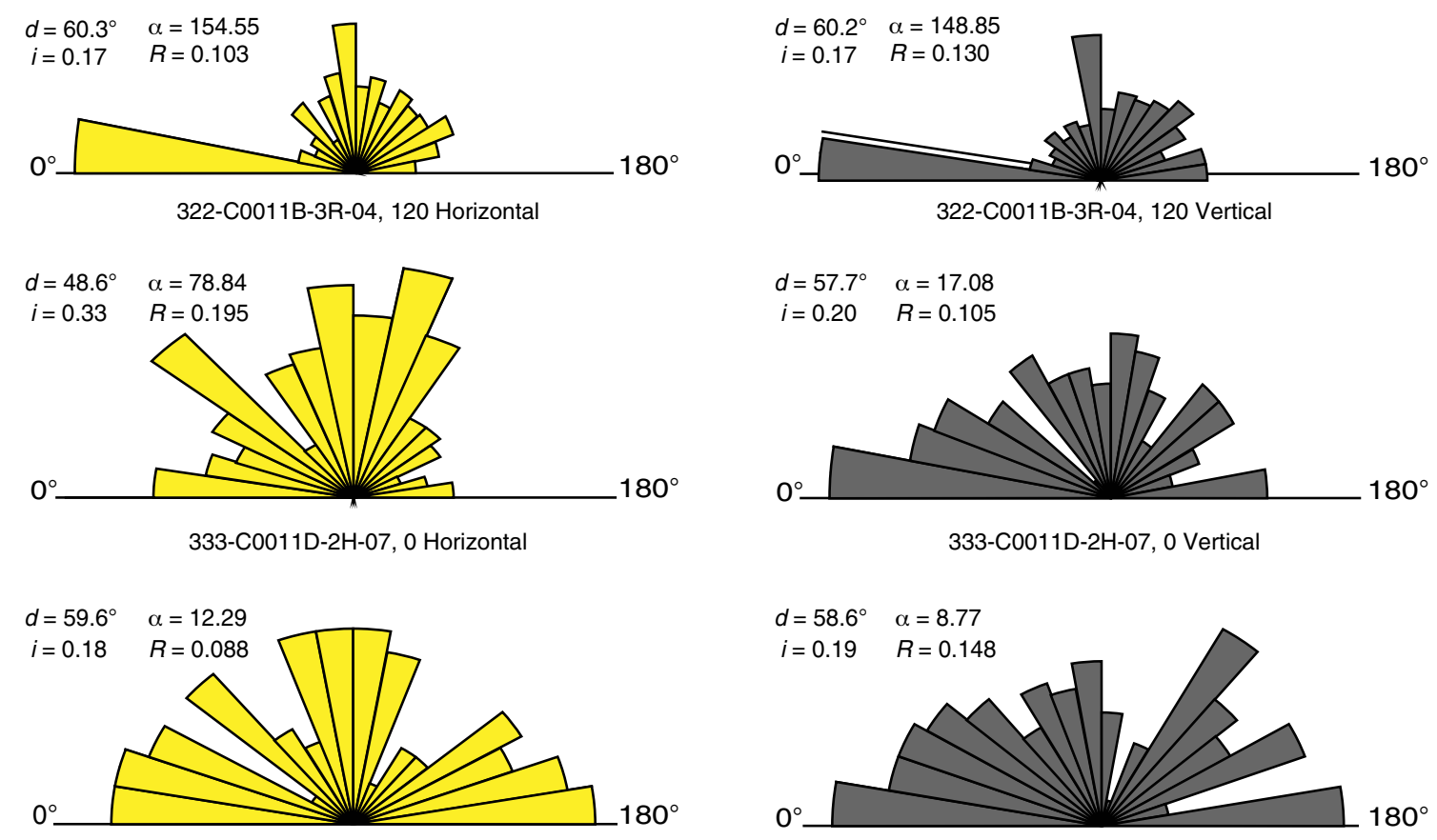

333-C0011D-19H-05, 99 Horizontal
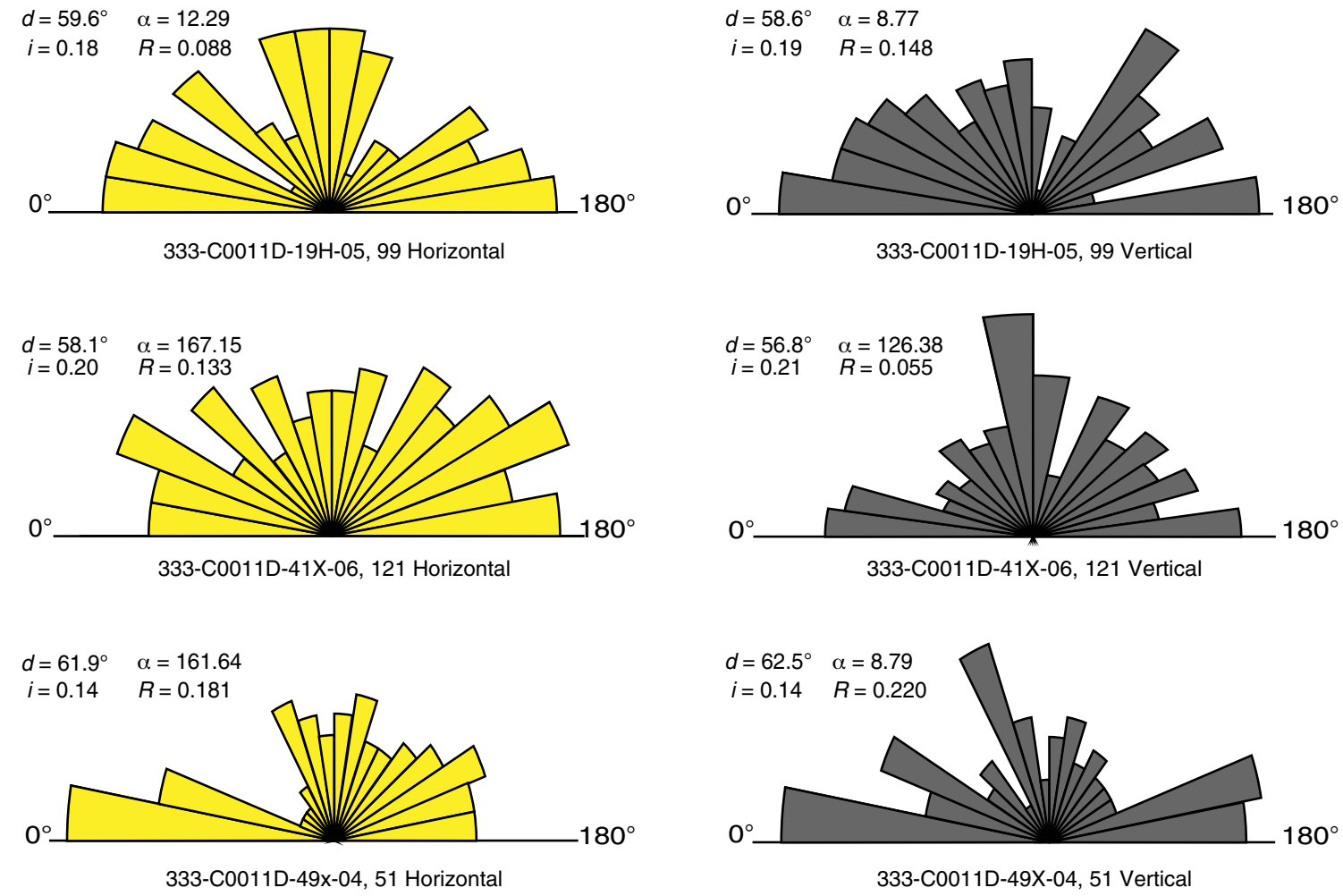
Figure F9 (continued).
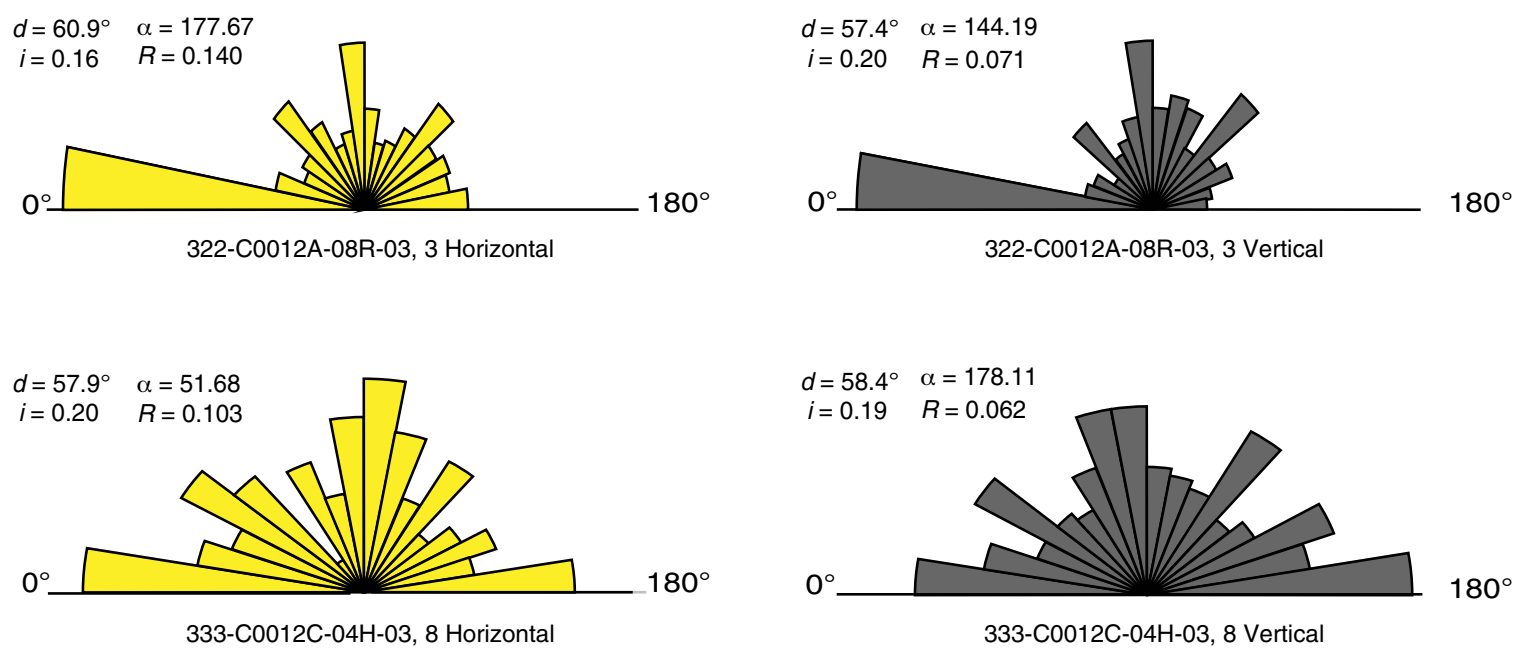

$d=58.7^{\circ} \quad \alpha=167.89$

$i=0.19 \quad R=0.114$
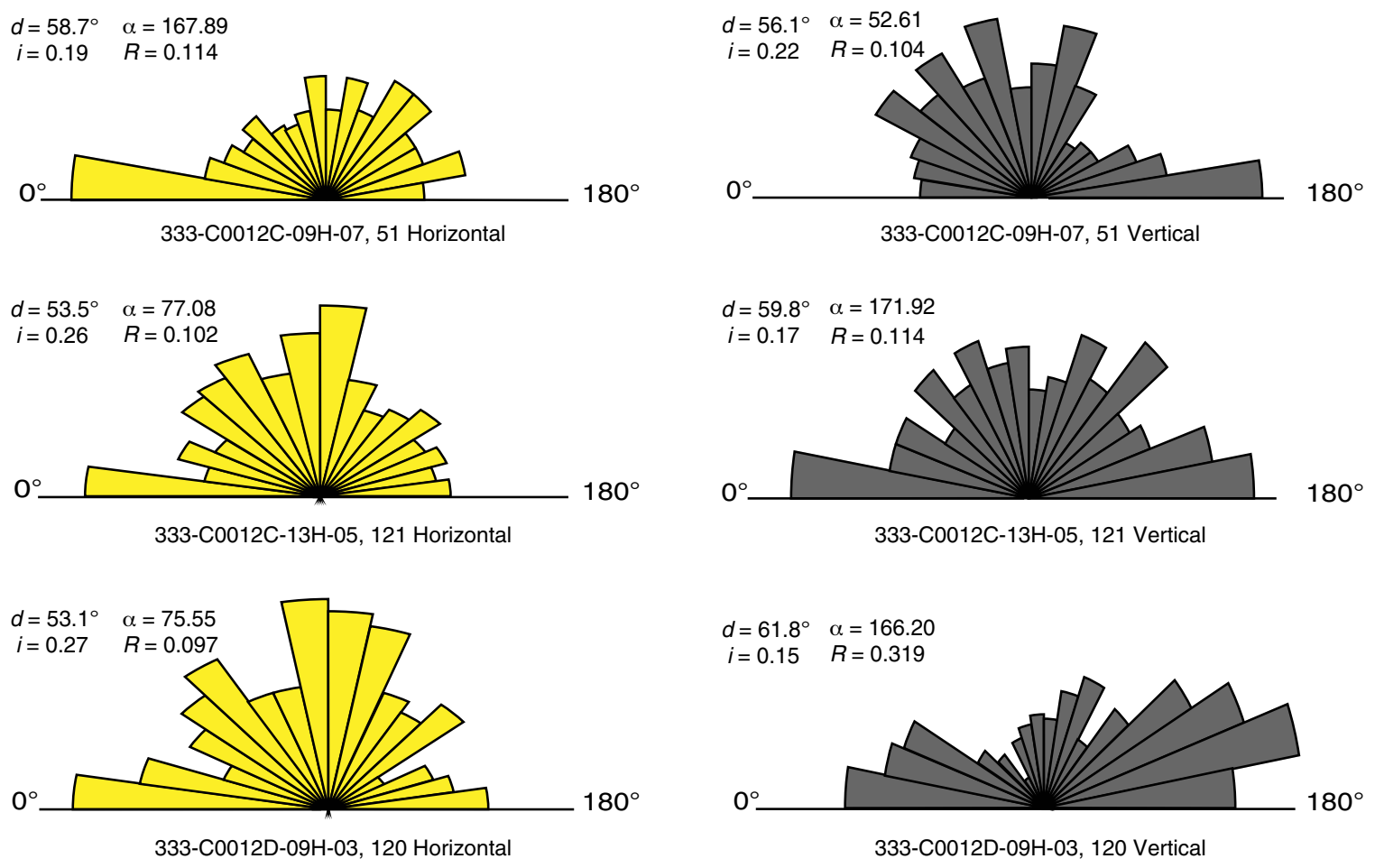
Figure F10. Cumulative frequency curves for grain orientations on horizontal sections (perpendicular to core axis) and vertical sections (parallel to core axis) imaged by environmental scanning electron microscope, Sites C0011 and C0012.
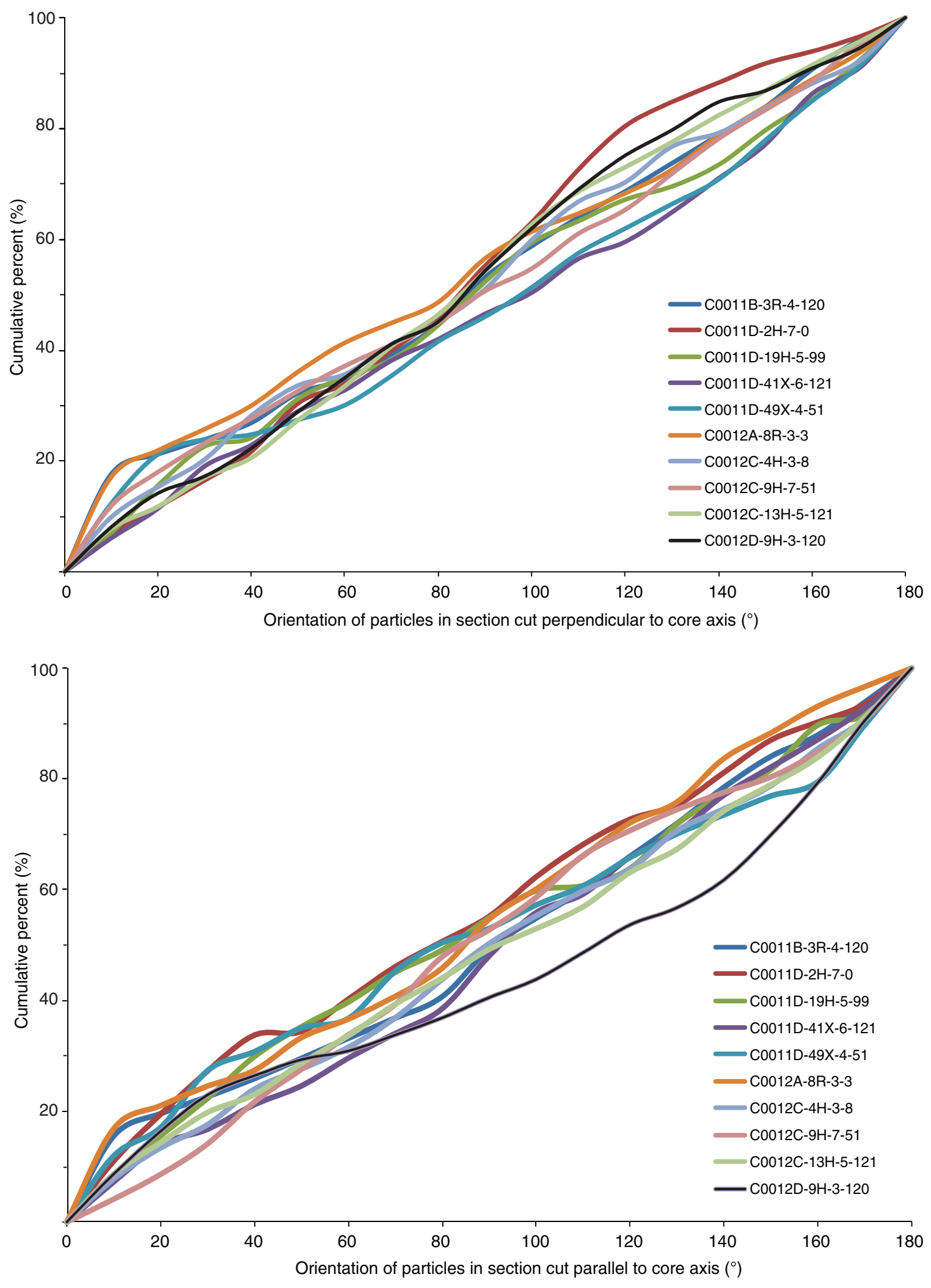
Figure F11. Depth-dependent trends in the index of orientation (for horizontal and vertical sections) and the anisotropy of permeability $\left(k_{\mathrm{h}} / k_{\mathrm{v}}\right)$, Sites C0011 and C0012.
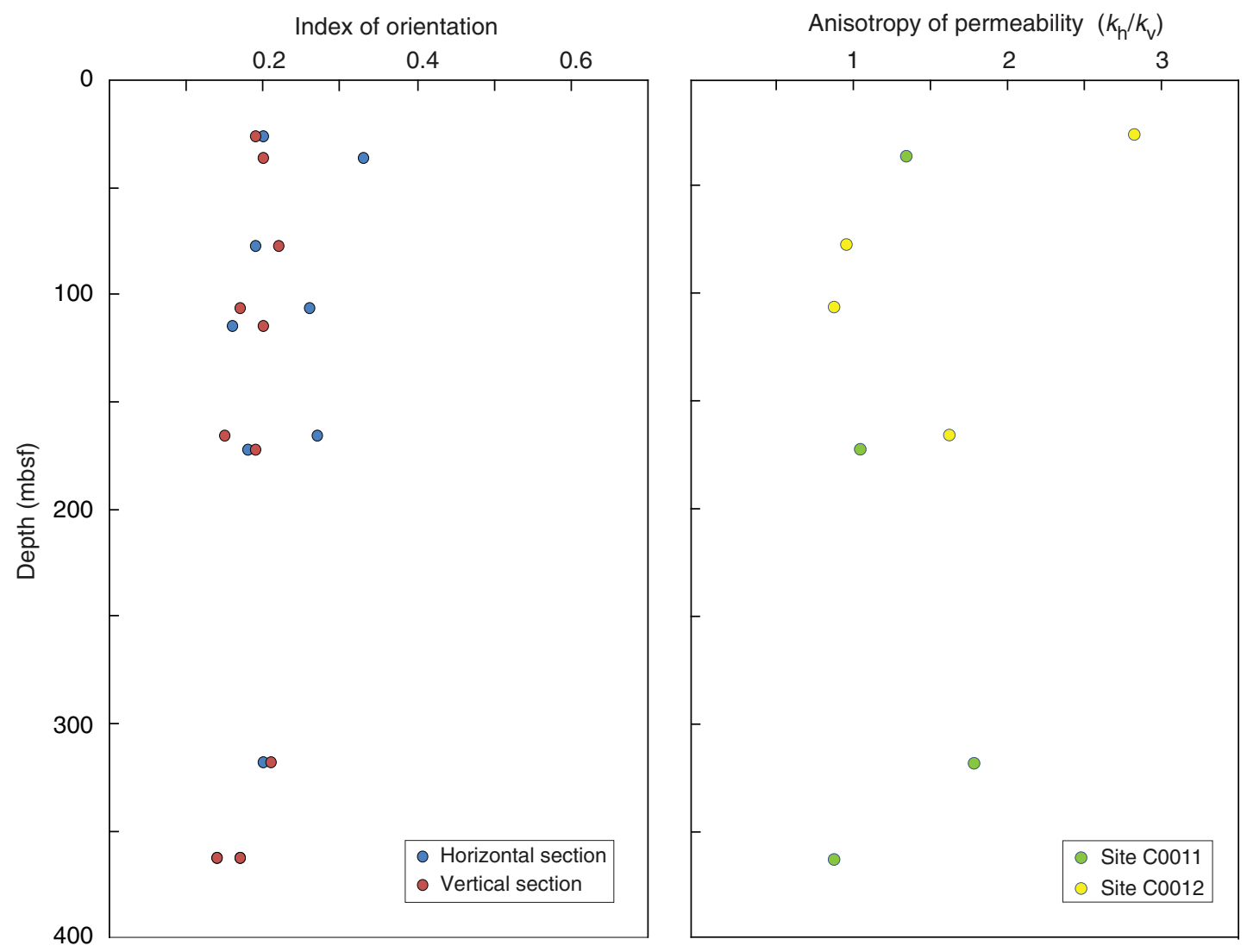


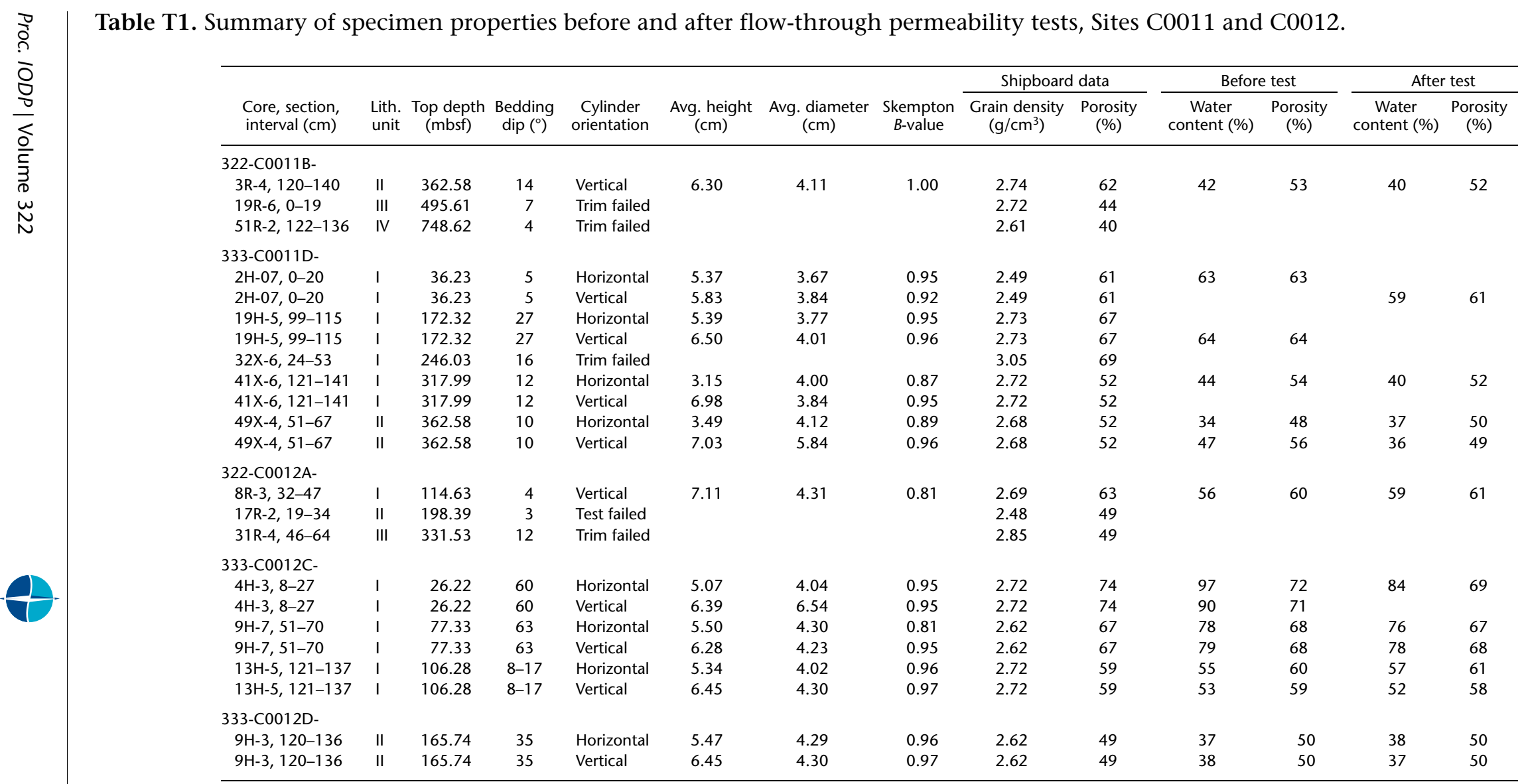


Table T2. Results of individual flow-through permeability tests, Sites C0011 and C0012. Note that some tests failed because of a faulty pressure transducer. (Continued on next page.)

\begin{tabular}{|c|c|c|c|c|c|c|c|}
\hline $\begin{array}{l}\text { Core, section, interval } \\
(\mathrm{cm})\end{array}$ & $\begin{array}{l}\text { Test } \\
\text { run }\end{array}$ & $\begin{array}{l}\text { Volumetric flow } \\
\text { rate }\left(\mathrm{cm}^{3} / \mathrm{min}\right)\end{array}$ & $\begin{array}{l}\text { Discharge velocity } \\
(\mathrm{cm} / \mathrm{s})\end{array}$ & $\begin{array}{l}\text { Head difference } \\
(\mathrm{cm})\end{array}$ & $\begin{array}{l}\text { Hydraulic } \\
\text { gradient }\end{array}$ & $\begin{array}{c}\text { Hydraulic } \\
\text { conductivity }(\mathrm{cm} / \mathrm{s})\end{array}$ & $\begin{array}{c}\text { Intrinsic } \\
\text { permeability }\left(\mathrm{m}^{2}\right)\end{array}$ \\
\hline \multicolumn{8}{|l|}{ 322-C0011B- } \\
\hline \multirow[t]{5}{*}{ 3R-4, 120 vertical } & 1 & 0.00005 & $6.28 \mathrm{E}-08$ & 331 & 52.54 & $2.39 \mathrm{E}-09$ & 2.37E-18 \\
\hline & 2 & -0.00005 & $-6.28 \mathrm{E}-08$ & -339 & -53.81 & $1.16 \mathrm{E}-08$ & $1.15 \mathrm{E}-17$ \\
\hline & 3 & 0.00003 & 3.77E-08 & 136 & 21.59 & $2.33 \mathrm{E}-09$ & $2.31 \mathrm{E}-18$ \\
\hline & 4 & -0.00003 & $-3.77 \mathrm{E}-08$ & -142 & -22.54 & $1.11 \mathrm{E}-08$ & $1.10 \mathrm{E}-17$ \\
\hline & & & & & Average: & $6.86 \mathrm{E}-09$ & $6.80 \mathrm{E}-18$ \\
\hline \multicolumn{8}{|l|}{ 333-C0011D- } \\
\hline \multirow{5}{*}{$2 \mathrm{H}-07,0$ horizontal } & 1 & -0.0005 & $-7.88 \mathrm{E}-07$ & -271 & -50.47 & $1.56 \mathrm{E}-08$ & $1.55 \mathrm{E}-17$ \\
\hline & 2 & -0.0008 & $-1.26 \mathrm{E}-06$ & -402 & -74.86 & $1.68 \mathrm{E}-08$ & $1.67 \mathrm{E}-17$ \\
\hline & 3 & 0.0005 & $7.88 \mathrm{E}-07$ & 218 & 40.60 & $1.94 \mathrm{E}-08$ & $1.93 \mathrm{E}-17$ \\
\hline & 4 & 0.0008 & $1.26 \mathrm{E}-06$ & 363 & 67.60 & $1.86 \mathrm{E}-08$ & $1.85 \mathrm{E}-17$ \\
\hline & & & & & Average: & $1.76 \mathrm{E}-08$ & $1.75 \mathrm{E}-17$ \\
\hline \multirow[t]{5}{*}{$2 \mathrm{H}-07,0$ vertical } & 1 & 0.001 & $1.44 \mathrm{E}-06$ & 660 & 113.21 & $1.27 \mathrm{E}-08$ & $1.26 \mathrm{E}-17$ \\
\hline & 2 & 0.0008 & $1.15 \mathrm{E}-06$ & 520 & 89.19 & $1.29 \mathrm{E}-08$ & $1.28 \mathrm{E}-17$ \\
\hline & 3 & -0.001 & $-1.44 \mathrm{E}-06$ & -630 & -108.06 & $1.33 \mathrm{E}-08$ & $1.32 \mathrm{E}-17$ \\
\hline & 4 & -0.0008 & $-1.15 \mathrm{E}-06$ & -501 & -85.93 & $1.34 \mathrm{E}-08$ & $1.33 \mathrm{E}-17$ \\
\hline & & & & & Average: & $1.31 \mathrm{E}-08$ & $1.30 \mathrm{E}-17$ \\
\hline \multirow[t]{5}{*}{$19 \mathrm{H}-05,99$ horizontal } & 1 & 0.0008 & $1.19 \mathrm{E}-06$ & 578 & 107.24 & $1.11 \mathrm{E}-08$ & $1.10 \mathrm{E}-17$ \\
\hline & 2 & 0.0005 & 7.47E-07 & 353 & 65.49 & $1.14 \mathrm{E}-08$ & $1.13 \mathrm{E}-17$ \\
\hline & 3 & -0.0008 & $-1.19 \mathrm{E}-06$ & -582 & -107.98 & $1.11 \mathrm{E}-08$ & $1.10 \mathrm{E}-17$ \\
\hline & 4 & -0.0005 & $-7.47 \mathrm{E}-07$ & -374 & -69.39 & $1.08 \mathrm{E}-08$ & $1.07 \mathrm{E}-17$ \\
\hline & & & & & Average: & $1.11 \mathrm{E}-08$ & $1.10 \mathrm{E}-17$ \\
\hline \multirow[t]{5}{*}{$19 \mathrm{H}-05,99$ vertical } & 1 & 0.0008 & $1.06 \mathrm{E}-06$ & 633 & 97.38 & $1.08 \mathrm{E}-08$ & $1.07 \mathrm{E}-17$ \\
\hline & 2 & 0.0005 & $6.60 \mathrm{E}-07$ & 392 & 60.31 & $1.09 \mathrm{E}-08$ & $1.08 \mathrm{E}-17$ \\
\hline & 3 & -0.0008 & $-1.06 \mathrm{E}-06$ & -632 & -97.23 & $1.09 \mathrm{E}-08$ & $1.08 \mathrm{E}-17$ \\
\hline & 4 & -0.0005 & $-6.60 \mathrm{E}-07$ & -415 & -63.85 & $1.03 \mathrm{E}-08$ & $1.02 \mathrm{E}-17$ \\
\hline & & & & & Average: & $1.07 \mathrm{E}-08$ & $1.06 \mathrm{E}-17$ \\
\hline \multirow[t]{5}{*}{$41 \mathrm{X}-06,121$ horizontal } & 1 & 0.00003 & $3.98 \mathrm{E}-08$ & 200 & 63.49 & $6.27 \mathrm{E}-10$ & $6.22 \mathrm{E}-19$ \\
\hline & 2 & -0.00005 & $-6.63 \mathrm{E}-08$ & -304 & -96.51 & $6.87 \mathrm{E}-10$ & $6.82 \mathrm{E}-19$ \\
\hline & 3 & -0.00003 & $-3.98 \mathrm{E}-08$ & - & - & - & - \\
\hline & 4 & 0.00005 & $6.63 \mathrm{E}-08$ & - & - & 一 & 一 \\
\hline & & & & & Average: & $6.57 \mathrm{E}-10$ & $6.52 \mathrm{E}-19$ \\
\hline \multirow[t]{5}{*}{$41 X-06,121$ vertical } & 1 & 0.00001 & $1.44 \mathrm{E}-08$ & 303 & 43.41 & $3.32 \mathrm{E}-10$ & 3.30E-19 \\
\hline & 2 & 0.00002 & $2.88 \mathrm{E}-08$ & 587 & 84.10 & $3.42 \mathrm{E}-10$ & 3.39E-19 \\
\hline & 3 & -0.00001 & $-1.44 \mathrm{E}-08$ & -251 & -35.96 & $4.00 \mathrm{E}-10$ & 3.97E-19 \\
\hline & 4 & -0.00002 & $-2.88 \mathrm{E}-08$ & -495 & -70.92 & $4.06 \mathrm{E}-10$ & 4.03E-19 \\
\hline & & & & & Average: & $3.70 \mathrm{E}-10$ & $3.67 \mathrm{E}-19$ \\
\hline \multirow[t]{5}{*}{$49 X-04,51$ horizontal } & 1 & 0.00005 & $6.25 \mathrm{E}-08$ & 424 & 121.49 & $5.15 \mathrm{E}-10$ & $5.11 \mathrm{E}-19$ \\
\hline & 2 & 0.00002 & $2.50 \mathrm{E}-08$ & 176 & 50.43 & $4.96 \mathrm{E}-10$ & $4.92 \mathrm{E}-19$ \\
\hline & 3 & -0.0003 & $-3.75 \mathrm{E}-07$ & - & - & - & - \\
\hline & 4 & -0.0005 & $-6.25 E-07$ & - & - & 一 & 一 \\
\hline & & & & & Average: & $5.06 \mathrm{E}-10$ & $5.02 \mathrm{E}-19$ \\
\hline \multirow[t]{5}{*}{$49 X-04,51$ vertical } & 1 & 0.00005 & $3.11 \mathrm{E}-08$ & 378 & 53.77 & $5.79 \mathrm{E}-10$ & $5.75 \mathrm{E}-19$ \\
\hline & 2 & 0.0003 & $1.87 \mathrm{E}-07$ & - & - & - & - \\
\hline & 3 & -0.00005 & $-3.11 \mathrm{E}-08$ & - & - & - & - \\
\hline & 4 & -0.0003 & $-1.87 \mathrm{E}-07$ & - & - & - & - \\
\hline & & & & & Average: & $5.79 \mathrm{E}-10$ & $5.75 \mathrm{E}-19$ \\
\hline \multicolumn{8}{|l|}{ 322-C0012A- } \\
\hline \multirow[t]{5}{*}{$8 \mathrm{R}-3,3$ vertical } & 1 & 0.0001 & $1.14 \mathrm{E}-07$ & 131 & 18.45 & $1.58 \mathrm{E}-08$ & $1.57 \mathrm{E}-17$ \\
\hline & 2 & 0.0002 & $2.29 \mathrm{E}-07$ & 173 & 24.37 & $2.39 \mathrm{E}-08$ & 2.37E-17 \\
\hline & 3 & -0.0001 & $-1.14 \mathrm{E}-07$ & -299 & -42.11 & $6.92 \mathrm{E}-09$ & $6.87 \mathrm{E}-18$ \\
\hline & 4 & -0.0002 & $-2.29 \mathrm{E}-07$ & -365 & -51.41 & $1.13 \mathrm{E}-08$ & $1.12 \mathrm{E}-17$ \\
\hline & & & & & Average: & $1.45 \mathrm{E}-08$ & $1.44 \mathrm{E}-17$ \\
\hline 333-C0012C- & & & & & & & \\
\hline $4 \mathrm{H}-03,8$ horizontal & 1 & 0.001 & $1.30 \mathrm{E}-06$ & 166 & 32.74 & $3.97 \mathrm{E}-08$ & $3.94 \mathrm{E}-17$ \\
\hline & 2 & 0.003 & $3.90 \mathrm{E}-06$ & 515 & 101.58 & $3.84 \mathrm{E}-08$ & $3.81 \mathrm{E}-17$ \\
\hline & 3 & -0.001 & $-1.30 \mathrm{E}-06$ & -182 & -35.90 & $3.62 \mathrm{E}-08$ & $3.59 \mathrm{E}-17$ \\
\hline & 4 & -0.003 & $-3.90 \mathrm{E}-06$ & -525 & -103.55 & 3.77E-08 & $3.74 \mathrm{E}-17$ \\
\hline & & & & & Average: & $3.80 \mathrm{E}-08$ & $3.77 \mathrm{E}-17$ \\
\hline $4 \mathrm{H}-03,8$ vertical & 1 & 0.001 & $4.96 \mathrm{E}-07$ & 248 & 38.81 & $1.28 \mathrm{E}-08$ & $1.27 \mathrm{E}-17$ \\
\hline & 2 & -0.0005 & $-2.48 \mathrm{E}-07$ & -112 & -17.53 & $1.42 \mathrm{E}-08$ & $1.40 \mathrm{E}-17$ \\
\hline & 3 & -0.001 & $-4.96 \mathrm{E}-07$ & - & - & - & - \\
\hline & 4 & 0.0005 & $2.48 \mathrm{E}-07$ & - & - & - & - \\
\hline
\end{tabular}


Table T2 (continued).

\begin{tabular}{|c|c|c|c|c|c|c|c|}
\hline $\begin{array}{l}\text { Core, section, interval } \\
(\mathrm{cm})\end{array}$ & $\begin{array}{l}\text { Test } \\
\text { run }\end{array}$ & $\begin{array}{l}\text { Volumetric flow } \\
\text { rate }\left(\mathrm{cm}^{3} / \mathrm{min}\right)\end{array}$ & $\begin{array}{l}\text { Discharge velocity } \\
(\mathrm{cm} / \mathrm{s})\end{array}$ & $\begin{array}{l}\text { Head difference } \\
\qquad(\mathrm{cm})\end{array}$ & $\begin{array}{l}\text { Hydraulic } \\
\text { gradient }\end{array}$ & $\begin{array}{c}\text { Hydraulic } \\
\text { conductivity }(\mathrm{cm} / \mathrm{s})\end{array}$ & $\begin{array}{c}\text { Intrinsic } \\
\text { permeability }\left(\mathrm{m}^{2}\right)\end{array}$ \\
\hline & & & & & Average: & $1.35 \mathrm{E}-08$ & $1.34 \mathrm{E}-17$ \\
\hline \multirow[t]{5}{*}{$9 \mathrm{H}-07,51$ horizontal } & 1 & 0.001 & $1.15 \mathrm{E}-06$ & 206 & 37.45 & $3.06 \mathrm{E}-08$ & $3.04 \mathrm{E}-17$ \\
\hline & 2 & 0.002 & $2.30 \mathrm{E}-06$ & 410 & 74.55 & $3.08 \mathrm{E}-08$ & $3.06 \mathrm{E}-17$ \\
\hline & 3 & -0.001 & $-1.15 \mathrm{E}-06$ & -205 & -37.27 & $3.08 \mathrm{E}-08$ & $3.06 \mathrm{E}-17$ \\
\hline & 4 & -0.002 & $-2.30 \mathrm{E}-06$ & -408 & -74.18 & $3.09 \mathrm{E}-08$ & $3.07 \mathrm{E}-17$ \\
\hline & & & & & Average: & $3.08 \mathrm{E}-08$ & $3.06 \mathrm{E}-17$ \\
\hline \multirow[t]{5}{*}{$9 \mathrm{H}-07,51$ vertical } & 1 & 0.001 & $1.19 \mathrm{E}-06$ & 224 & 35.67 & $3.32 \mathrm{E}-08$ & $3.30 \mathrm{E}-17$ \\
\hline & 2 & 0.002 & $2.37 \mathrm{E}-06$ & 462 & 73.57 & $3.22 \mathrm{E}-08$ & $3.20 \mathrm{E}-17$ \\
\hline & 3 & -0.001 & $-1.19 \mathrm{E}-06$ & -232 & -36.94 & $3.21 \mathrm{E}-08$ & $3.19 \mathrm{E}-17$ \\
\hline & 4 & -0.002 & $-2.37 \mathrm{E}-06$ & -460 & -73.25 & $3.24 \mathrm{E}-08$ & $3.21 \mathrm{E}-17$ \\
\hline & & & & & Average: & $3.25 \mathrm{E}-08$ & $3.23 \mathrm{E}-17$ \\
\hline \multirow[t]{5}{*}{$13 \mathrm{H}-05,121$ horizontal } & 1 & 0.0001 & $1.31 \mathrm{E}-07$ & 220 & 41.20 & $3.19 \mathrm{E}-09$ & $3.16 \mathrm{E}-18$ \\
\hline & 2 & 0.0002 & $2.63 \mathrm{E}-07$ & 456 & 85.39 & $3.08 \mathrm{E}-09$ & $3.05 \mathrm{E}-18$ \\
\hline & 3 & -0.0001 & $-1.31 \mathrm{E}-07$ & -233 & -43.63 & $3.01 \mathrm{E}-09$ & $2.99 \mathrm{E}-18$ \\
\hline & 4 & -0.0002 & $-2.63 \mathrm{E}-07$ & -460 & -86.14 & $3.05 \mathrm{E}-09$ & $3.03 \mathrm{E}-18$ \\
\hline & & & & & Average: & $3.08 \mathrm{E}-09$ & $3.06 \mathrm{E}-18$ \\
\hline \multirow[t]{5}{*}{$13 \mathrm{H}-05,121$ vertical } & 1 & 0.0001 & $1.15 \mathrm{E}-07$ & 203 & 31.47 & $3.65 \mathrm{E}-09$ & $3.62 \mathrm{E}-18$ \\
\hline & 2 & 0.0002 & $2.30 \mathrm{E}-07$ & 385 & 59.69 & $3.85 \mathrm{E}-09$ & $3.82 \mathrm{E}-18$ \\
\hline & 3 & -0.0001 & $-1.15 \mathrm{E}-07$ & -211 & -32.71 & $3.51 \mathrm{E}-09$ & $3.48 \mathrm{E}-18$ \\
\hline & 4 & -0.0002 & $-2.30 \mathrm{E}-07$ & -465 & -72.09 & $3.18 \mathrm{E}-09$ & $3.16 \mathrm{E}-18$ \\
\hline & & & & & Average: & $3.55 \mathrm{E}-09$ & $3.52 \mathrm{E}-18$ \\
\hline \multicolumn{8}{|l|}{ 333-C0012D- } \\
\hline \multirow[t]{5}{*}{$9 \mathrm{H}-03,120$ horizontal } & 1 & 0.0001 & $1.15 \mathrm{E}-07$ & 198 & 36.20 & 3.19E-09 & $3.16 \mathrm{E}-18$ \\
\hline & 2 & 0.0002 & $2.31 \mathrm{E}-07$ & 550 & 100.55 & $2.29 \mathrm{E}-09$ & $2.28 \mathrm{E}-18$ \\
\hline & 3 & -0.0001 & $-1.15 E-07$ & - & - & - & - \\
\hline & 4 & -0.0002 & $-2.31 \mathrm{E}-07$ & - & - & 一 & 一 \\
\hline & & & & & Average: & $2.74 \mathrm{E}-09$ & $2.72 \mathrm{E}-18$ \\
\hline \multirow[t]{5}{*}{$9 \mathrm{H}-03,120$ vertical } & 1 & 0.0001 & $1.15 \mathrm{E}-07$ & 350 & 54.26 & $2.12 \mathrm{E}-09$ & $2.10 \mathrm{E}-18$ \\
\hline & 2 & 0.00008 & $9.18 \mathrm{E}-08$ & 292 & 45.27 & $2.03 \mathrm{E}-09$ & $2.01 \mathrm{E}-18$ \\
\hline & 3 & -0.0001 & $-1.15 \mathrm{E}-07$ & -513 & -79.53 & $1.44 \mathrm{E}-09$ & $1.43 \mathrm{E}-18$ \\
\hline & 4 & -0.00008 & $-9.18 \mathrm{E}-08$ & -502 & -77.83 & $1.18 \mathrm{E}-09$ & 1.17E-18 \\
\hline & & & & & Average: & $1.69 \mathrm{E}-09$ & $1.68 \mathrm{E}-18$ \\
\hline
\end{tabular}

Table T3. Statistics for mudstone microfabric calculated from analyses of environmental scanning electron microscope images, Sites C0011 and C0012.

\begin{tabular}{|c|c|c|c|c|c|c|c|c|c|c|c|}
\hline \multirow[b]{2}{*}{$\begin{array}{l}\text { Core, section, } \\
\text { interval }(\mathrm{cm})\end{array}$} & \multirow[b]{2}{*}{$\begin{array}{c}\text { Top depth } \\
\text { (mbsf) }\end{array}$} & \multicolumn{5}{|c|}{ Horizontal section } & \multicolumn{5}{|c|}{ Vertical section } \\
\hline & & $\begin{array}{l}\text { Grains } \\
\text { counted }\end{array}$ & $\begin{array}{l}\text { Stand. dev. } \\
\text { orientation } \\
\left({ }^{\circ}\right)\end{array}$ & $\begin{array}{l}\text { Index of } \\
\text { orientation }\end{array}$ & $\begin{array}{c}\text { Mean } \\
\text { angle }\left({ }^{\circ}\right)\end{array}$ & $\begin{array}{l}\text { Resultant } \\
\text { vector } \\
\text { length }\end{array}$ & $\begin{array}{l}\text { Grains } \\
\text { counted }\end{array}$ & $\begin{array}{l}\text { Stand. dev. } \\
\text { orientation } \\
\left({ }^{\circ}\right)\end{array}$ & $\begin{array}{l}\text { Index of } \\
\text { orientation }\end{array}$ & $\begin{array}{c}\text { Mean } \\
\text { angle }\left({ }^{\circ}\right)\end{array}$ & $\begin{array}{l}\text { Resultant } \\
\text { vector } \\
\text { length }\end{array}$ \\
\hline $\begin{array}{c}322-\mathrm{C} 0011 \mathrm{~B}- \\
3 \mathrm{R}-4,120\end{array}$ & 362.58 & 769 & 60.3 & 0.17 & 154.44 & 0.103 & 521 & 60.2 & 0.17 & 148.85 & 0.130 \\
\hline $\begin{array}{c}333-\mathrm{C} 0011 \mathrm{D}- \\
2 \mathrm{H}-07,0 \\
19 \mathrm{H}-05,99 \\
41 \mathrm{X}-06,121 \\
49 \mathrm{X}-04,51\end{array}$ & $\begin{array}{r}36.33 \\
172.32 \\
317.99 \\
362.58\end{array}$ & $\begin{array}{l}230 \\
128 \\
131 \\
113\end{array}$ & $\begin{array}{l}48.6 \\
59.6 \\
58.1 \\
61.9\end{array}$ & $\begin{array}{l}0.33 \\
0.18 \\
0.2 \\
0.14\end{array}$ & $\begin{array}{r}78.84 \\
12.29 \\
167.15 \\
161.64\end{array}$ & $\begin{array}{l}0.195 \\
0.088 \\
0.133 \\
0.181\end{array}$ & $\begin{array}{l}154 \\
224 \\
179 \\
117\end{array}$ & $\begin{array}{l}57.7 \\
58.6 \\
56.8 \\
62.5\end{array}$ & $\begin{array}{l}0.2 \\
0.19 \\
0.21 \\
0.14\end{array}$ & $\begin{array}{l}17.08 \\
8.77 \\
126.38 \\
8.79\end{array}$ & $\begin{array}{l}0.105 \\
0.148 \\
0.055 \\
0.220\end{array}$ \\
\hline $\begin{array}{l}322-\mathrm{C} 0012 \mathrm{~A}- \\
8 \mathrm{R}-3,3\end{array}$ & 114.63 & 1013 & 60.9 & 0.16 & 177.67 & 0.140 & 1018 & 57.4 & 0.2 & 144.19 & 0.071 \\
\hline $\begin{array}{c}333-\mathrm{C} 0012 \mathrm{C}- \\
4 \mathrm{H}-03,8 \\
9 \mathrm{H}-07,51 \\
13 \mathrm{H}-05,121\end{array}$ & $\begin{array}{r}26.22 \\
77.33 \\
106.28\end{array}$ & $\begin{array}{l}202 \\
444 \\
704\end{array}$ & $\begin{array}{l}57.9 \\
58.7 \\
53.5\end{array}$ & $\begin{array}{l}0.2 \\
0.19 \\
0.26\end{array}$ & $\begin{array}{r}51.68 \\
167.89 \\
77.08\end{array}$ & $\begin{array}{l}0.103 \\
0.114 \\
0.102\end{array}$ & $\begin{array}{l}358 \\
290 \\
404\end{array}$ & $\begin{array}{l}58.4 \\
56.1 \\
59.8\end{array}$ & $\begin{array}{l}0.19 \\
0.22 \\
0.17\end{array}$ & $\begin{array}{l}178.11 \\
52.61 \\
171.92\end{array}$ & $\begin{array}{l}0.062 \\
0.104 \\
0.114\end{array}$ \\
\hline $\begin{array}{r}333-\mathrm{C} 0012 \mathrm{D}- \\
9 \mathrm{H}-03,120\end{array}$ & 165.74 & 197 & 53.1 & 0.27 & 75.55 & 0.097 & 518 & 61.8 & 0.15 & 166.20 & 0.319 \\
\hline
\end{tabular}


Table T4. Average values of permeability and hydraulic conductivity for horizontal and vertical test directions, Sites C0011 and C0012.

\begin{tabular}{|c|c|c|c|c|c|c|}
\hline \multirow{2}{*}{$\begin{array}{l}\text { Core, section, } \\
\text { interval }(\mathrm{cm})\end{array}$} & \multirow{2}{*}{$\begin{array}{c}\text { Top depth } \\
\text { (mbsf) }\end{array}$} & \multicolumn{2}{|c|}{ Hydraulic conductivity $(\mathrm{cm} / \mathrm{s})$} & \multicolumn{2}{|c|}{ Intrinsic permeability $\left(\mathrm{m}^{2}\right)$} & \multirow[b]{2}{*}{$k_{\mathrm{h}} / k_{\mathrm{v}}$} \\
\hline & & Horizontal & Vertical & Horizontal & Vertical & \\
\hline $\begin{array}{c}322-\mathrm{C} 0011 \mathrm{~B}- \\
3 \mathrm{R}-4,120\end{array}$ & 362.58 & & $6.86 \mathrm{E}-09$ & & $6.80 \mathrm{E}-18$ & \\
\hline 333-C0011D- & & & & & & \\
\hline $\begin{array}{l}2 \mathrm{H}-07,0 \\
19 \mathrm{H}-05,99\end{array}$ & $\begin{array}{r}36.33 \\
172.32\end{array}$ & $\begin{array}{l}1.76 \mathrm{E}-08 \\
1.11 \mathrm{E}-08\end{array}$ & $\begin{array}{l}1.31 \mathrm{E}-08 \\
1.07 \mathrm{E}-08\end{array}$ & $\begin{array}{l}1.75 \mathrm{E}-17 \\
1.10 \mathrm{E}-17\end{array}$ & $\begin{array}{l}1.30 \mathrm{E}-17 \\
1.06 \mathrm{E}-17\end{array}$ & $\begin{array}{l}1.34 \\
1.04\end{array}$ \\
\hline $41 X-06,121$ & 317.99 & $6.57 \mathrm{E}-10$ & $3.70 \mathrm{E}-10$ & $6.52 \mathrm{E}-19$ & $3.67 \mathrm{E}-19$ & 1.78 \\
\hline $49 X-04,51$ & 362.58 & $5.06 \mathrm{E}-10$ & $5.79 \mathrm{E}-10$ & $5.02 \mathrm{E}-19$ & $5.75 \mathrm{E}-19$ & 0.87 \\
\hline $\begin{array}{l}322-\mathrm{C} 0012 \mathrm{~A}- \\
8 \mathrm{R}-3,3\end{array}$ & 114.63 & & $1.45 \mathrm{E}-08$ & & $1.44 \mathrm{E}-17$ & \\
\hline 333-C0012C- & & & & & & \\
\hline $\begin{array}{l}4 \mathrm{H}-03,8 \\
9 \mathrm{H}-07,51\end{array}$ & $\begin{array}{l}26.22 \\
77.33\end{array}$ & $\begin{array}{l}3.80 \mathrm{E}-08 \\
3.08 \mathrm{E}-08\end{array}$ & $\begin{array}{l}1.35 \mathrm{E}-08 \\
3.25 \mathrm{E}-08\end{array}$ & $\begin{array}{l}3.77 \mathrm{E}-17 \\
3.06 \mathrm{E}-17\end{array}$ & $\begin{array}{l}1.34 \mathrm{E}-17 \\
3.23 \mathrm{E}-17\end{array}$ & $\begin{array}{l}2.82 \\
0.95\end{array}$ \\
\hline $13 \mathrm{H}-05,121$ & 106.28 & $3.08 \mathrm{E}-09$ & $3.55 \mathrm{E}-09$ & $3.06 \mathrm{E}-18$ & $3.52 \mathrm{E}-18$ & 0.87 \\
\hline $\begin{array}{r}333-\mathrm{C} 0012 \mathrm{D}- \\
9 \mathrm{H}-03,120\end{array}$ & 165.74 & $2.74 \mathrm{E}-09$ & 1.69E-09 & $2.72 \mathrm{E}-18$ & $1.68 \mathrm{E}-18$ & 1.62 \\
\hline
\end{tabular}




\section{Appendix}

Plots of hydraulic gradient versus discharge velocity are presented in Figures AF1, AF2, AF3, AF4, and AF5. 
Figure AF1. Plot of hydraulic gradient versus discharge velocity, Samples 322-C0011B-3R-4, $120 \mathrm{~cm}$, and 333C0011D-2H-7, $0 \mathrm{~cm}$.
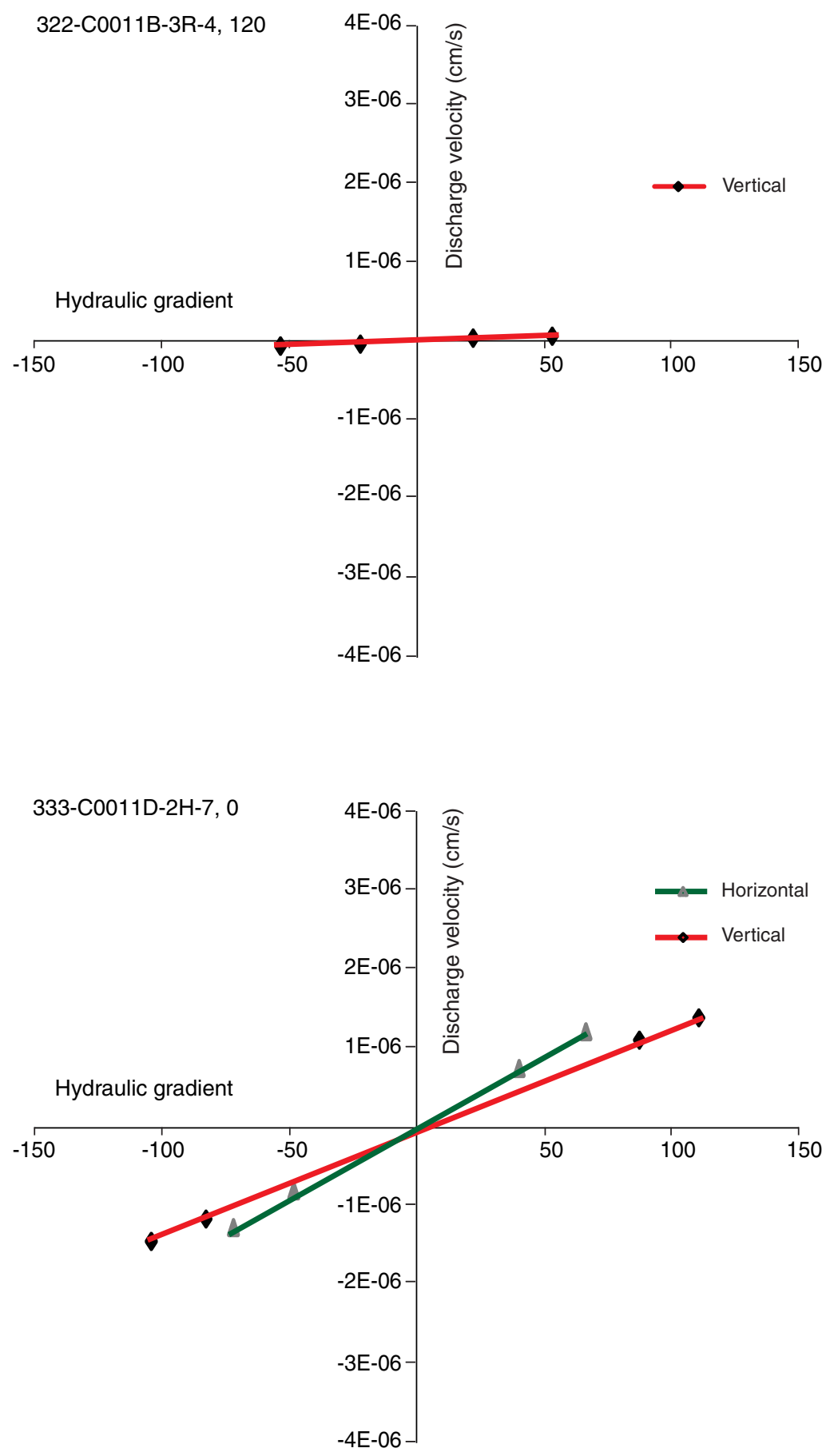
Figure AF2. Plot of hydraulic gradient versus discharge velocity, Samples 333-C0011D-19H-5, 99 cm, and 333C0011D-41X-6, $121 \mathrm{~cm}$.
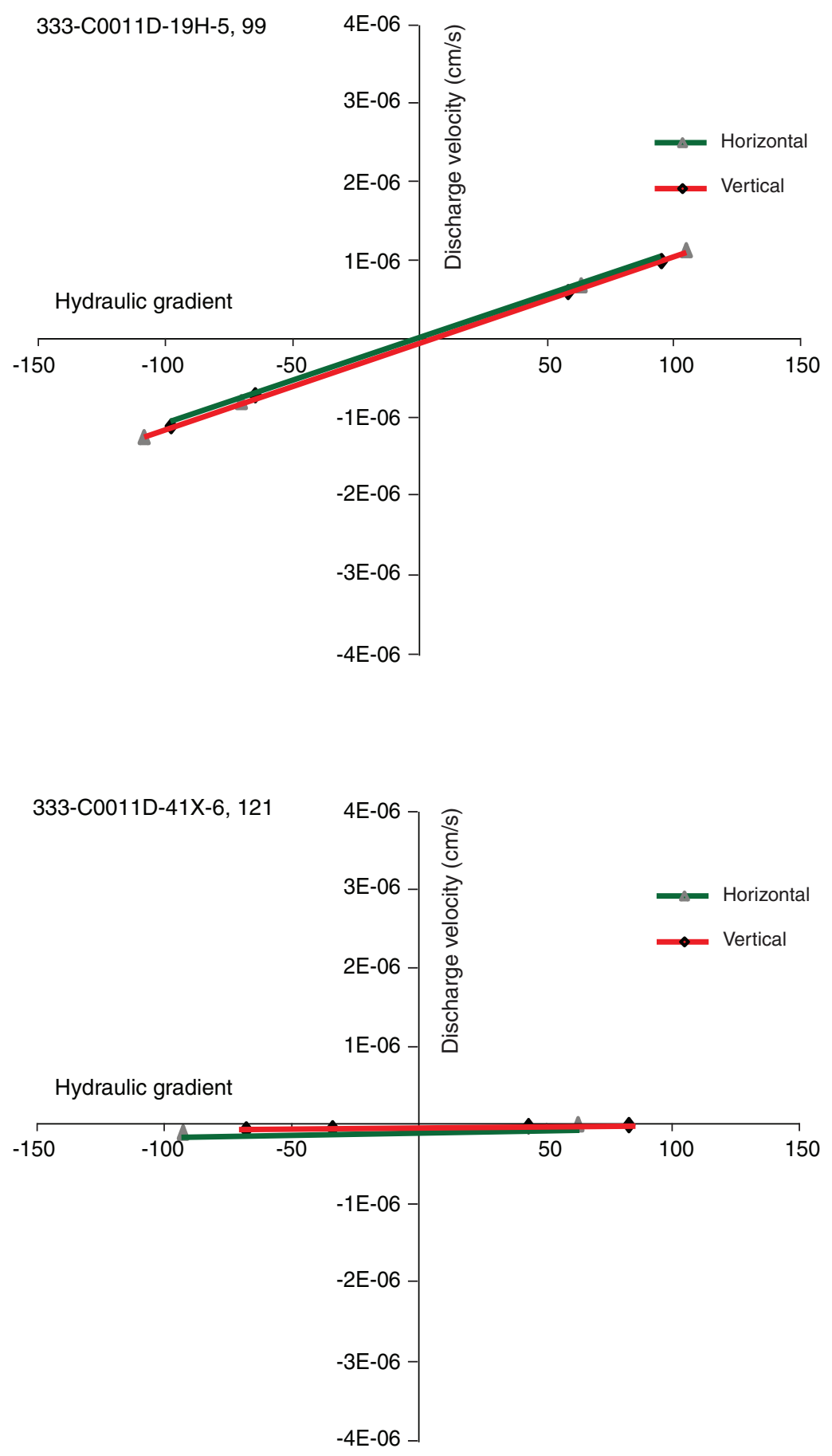
Figure AF3. Plot of hydraulic gradient versus discharge velocity, Samples 333-C0011D-49X-5, 60 cm, and $322-$ C0012A-8R-3, $3 \mathrm{~cm}$.
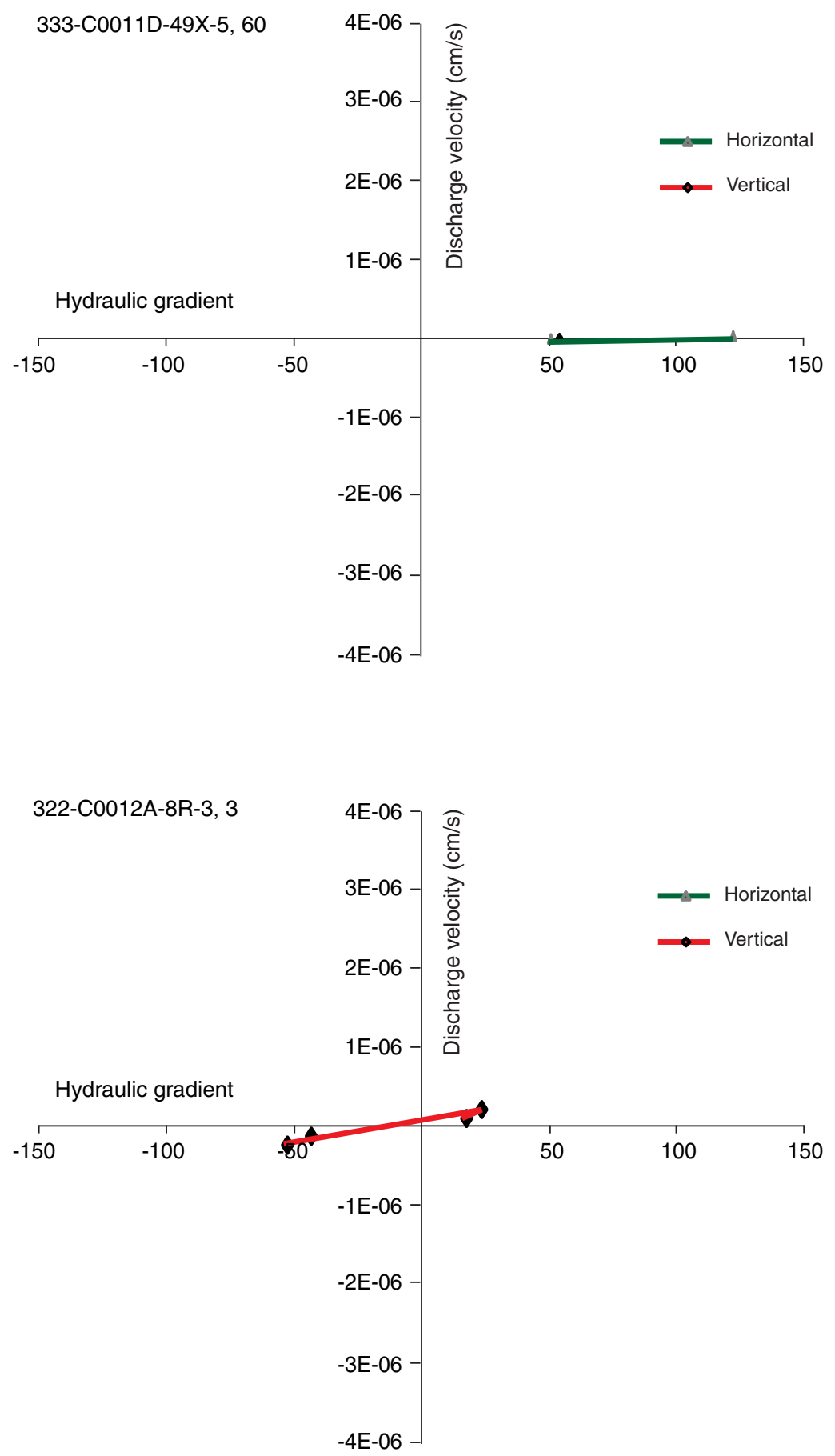
Figure AF4. Plot of hydraulic gradient versus discharge velocity, Samples 333-C0012C-4H-3, $8 \mathrm{~cm}$, and 333C0012C-9H-7, $51 \mathrm{~cm}$.
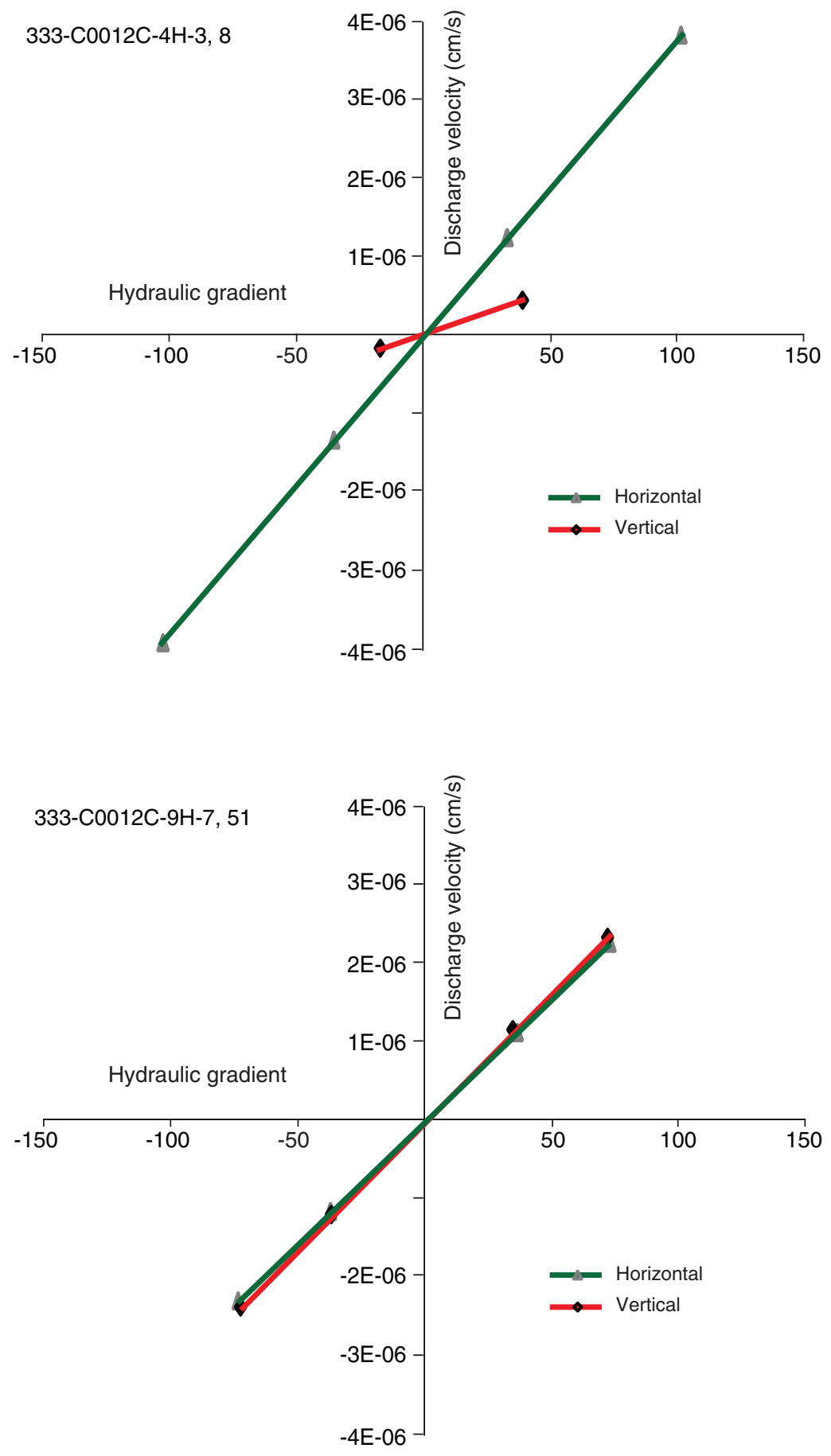
Figure AF5. Plot of hydraulic gradient versus discharge velocity, Samples 333-C--12C-13H-5, $121 \mathrm{~cm}$, and 333C0012D-9H-3, $120 \mathrm{~cm}$.

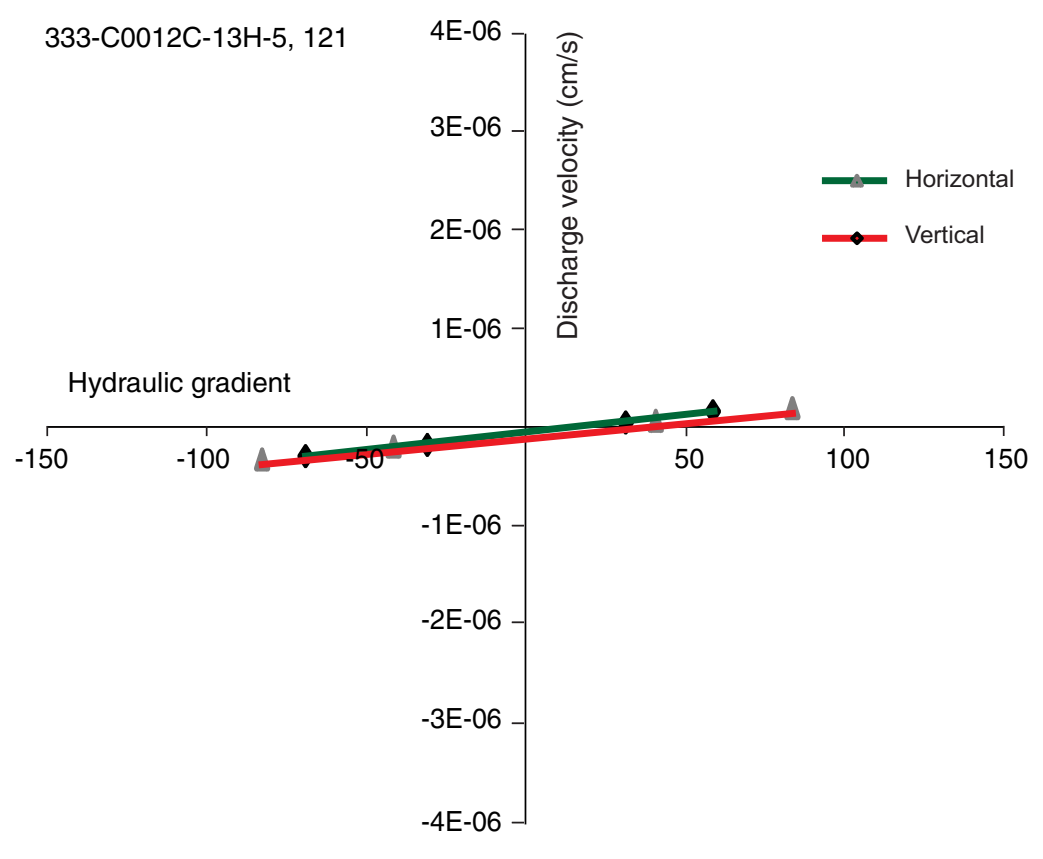

333-C0012D-9H-3, 120

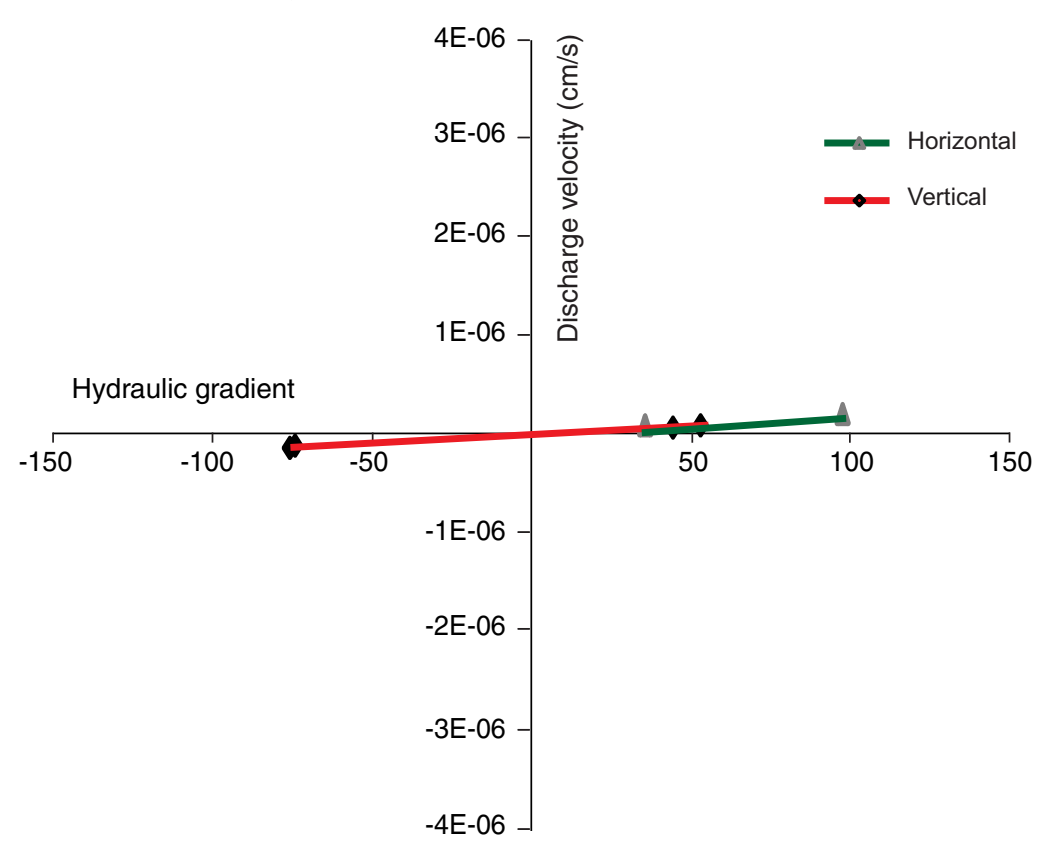

